\title{
Fumonisins: Impact on Agriculture, Food, and Human Health and their Management Strategies
}

\author{
Madhu Kamle ${ }^{1}$, Dipendra K. Mahato ${ }^{2}$, Sheetal Devi ${ }^{3}$, Kyung Eun Lee ${ }^{4}$, Sang G. Kang ${ }^{4,5, *}$ and \\ Pradeep Kumar ${ }^{1, * \mathbb{D}}$ \\ 1 Department of Forestry, North Eastern Regional Institute of Science and Technology, Nirjuli-791109, \\ Arunachal Pradesh, India; madhu.kamle18@gmail.com \\ 2 School of Exercise and Nutrition Sciences, Deakin University, 221 Burwood Hwy, Burwood VIC 3125, \\ Australia; kumar.dipendra2@gmail.com \\ 3 SAB Miller India Ltd., Sonipat, Haryana 131001, India; sheetaldeshwal1993@gmail.com \\ 4 Molecular Genetics Laboratory, Department of Biotechnology, Yeungnam University, 280 Daehak-Ro, \\ Gyeongsan, Gyeongbuk 38541, Korea; keun126@ynu.ac.kr \\ 5 Stemforce, 302 Institute of Industrial Technology, Yeungnam University, Gyeongsan, \\ Gyeongbuk 38541, Korea \\ * Correspondence: kangsg@yu.ac.kr (S.G.K.); pkbiotech@gmail.com (P.K.)
}

Received: 4 May 2019; Accepted: 4 June 2019; Published: 7 June 2019

\begin{abstract}
The fumonisins producing fungi, Fusarium spp., are ubiquitous in nature and contaminate several food matrices that pose detrimental health hazards on humans as well as on animals. This has necessitated profound research for the control and management of the toxins to guarantee better health of consumers. This review highlights the chemistry and biosynthesis process of the fumonisins, their occurrence, effect on agriculture and food, along with their associated health issues. In addition, the focus has been put on the detection and management of fumonisins to ensure safe and healthy food. The main focus of the review is to provide insights to the readers regarding their health-associated food consumption and possible outbreaks. Furthermore, the consumers' knowledge and an attempt will ensure food safety and security and the farmers' knowledge for healthy agricultural practices, processing, and management, important to reduce the mycotoxin outbreaks due to fumonisins.
\end{abstract}

Keywords: Fumonisins; Fusarium spp.; food contamination; health issues; secondary metabolites

Key Contribution: This review gives insight into the occurrence of fumonisins, their outbreak and effects on human health, and agriculture and food along with their management strategies.

\section{Introduction}

Fumonisins are secondary metabolites produced in cereals by pathogenic fungi, namely Fusarium verticillioides, Fusarium proliferatum, and related species [1]. Moreover, Aspergillus nigri also produces fumonisins in the crop plants of peanut, maize, and grape [2-6]. The maize and maize-based products are most commonly infected with fumonisins besides their presence in several other grains (rice, wheat, barley, maize, rye, oat, and millet) and grain products (tortillas, corn flask, chips) $[7,8]$ which have major influences on health. More than 15 fumonisin homologues have been known and characterized as fumonisin A, B, C, and P $[9,10]$. Further among fumonisin B, FB1, FB2, and FB3 are most abundant with FB1 being the most toxic form that can co-exists with other forms of fumonisin, i.e., FB2 and FB3 [11]. These (FB1, FB2, and FB3) forms are the main food contaminants. FB1 consists of a diester with propane-1,2,3-tricarboxylic acid (TCA) and 2-amino-12,16-dime thyl-3,5,10,14,15-pentahydroxyleicosane where hydroxyl (OH-) groups at the $\mathrm{C}-14$ and $\mathrm{C}-15$ positions 
involved with the carboxyl groups (-COOH) of TCA to form an ester. On the other hand, FB2 and FB3 are actually the C-5 and C-10 dehydroxy analogues of FB1 [12].

The toxins are linked with several health issues like cancer of the esophagus as evident from different regions of the world. Fumonisins are a very sensitive issue all around the world, which occur in Europe (51\%) and Asia (85\%) [13]. The occurrence of fumonisins with other related toxins in feed and food is reported in various countries like Argentina [14], Brazil [15], China [16], Italy [17], Portugal [18], Spain [19], Tanzania [20], and Thailand [21]. They are also reported to have toxic effects on the liver and nephron in all the tested animals [22]. In addition, FB1 is implicated with the incidences of hepatocarcinoma, stimulation and suppression of the immune system, defects in the neural-tube, nephrotoxicity, as well as other ailments. It is prominent as a promoter of hepatocarcinoma [23] where its synergistic interactions with aflatoxin B1 (AFB1) has been exhibited in animal models (rainbow trout and rats) for two stages, i.e., initiation and promotion of cancer [24-26]. The international agency for Research on Cancer (IARC) characterized FB1 as a group 2B possible carcinogen for human. Besides this, it can cause toxicity in several animals like rats, mice, and rabbits [27]. Further, a temporary maximum tolerable daily intake for fumonisins has been set as $2 \mu \mathrm{g} / \mathrm{kg}$ bw/day based on the lack of any observed adverse effects for nephrotoxicity in male rats by the joint Food and Agriculture Organization (FAO) and World Health Organization (WHO) [28].

\section{Major Source of Fumonisin}

Fumonisins are mainly produced by F. verticillioides and F. proliferatum and other Fusarium spp. The genus Fusarium, belonging to the family Nectriaceae, can be found as saprophytes in soil and plants worldwide [29]. Fusarium spp. colonize to the rhizospheres of plants and then subsequently enter into the plant system. Furthermore, F. verticillioides and F. proliferatum are known to be the most common pathogens of maize (Zea mays) [30]. Not only the crops, but also many popular ornamental plants (e.g., aster begonia, carnation, chrysanthemum, gladiolus, etc.) are frequently attacked by different Fusarium species, viz., F. oxysporum, F. foetens, F. hostae, and F. redolens at various stages of production [31].

Fusarium, on the other hand, infects orchids in both pathogenic and non-pathogenic forms. The non-pathogenic forms are either decomposers [32] or in mutual relation where they help in the germination of seeds and the color development of seedlings [33]. The non-pathogenic forms also help to mitigate the infection of Fusarium wilt on various crops [34]. Soils responsible for suppressing Fusarium wilt are found to be dominant in the Fusarium spp. like F. oxysporum and F. solani which are of agricultural importance $[35,36]$. The Fusarium species infect maize and produce fumonisins mainly at the pre-harvesting stage. Furthermore, fumonisin production has been observed during the post-harvest period; however, under adverse conditions of storage [37]. Dietary exposure of fumonisins can lead to several harmful outcomes in both farm and experimental laboratory animals. For example, these toxins are responsible for leukoencephalomalacia in horses [38], pulmonary edema syndrome in pigs [39], hepatotoxicity and nephrotoxicity in rats [40], and apoptosis in many other types of cells [41].

\section{Chemistry and Biosynthesis of Fumonisin}

Fumonisins (FBs) consist of two methyls $\left(-\mathrm{CH}_{3}\right)$, one amine $\left(-\mathrm{NH}_{2}\right)$, one to four hydroxyl $\left(-\mathrm{OH}^{-}\right)$, and two tricarboxylic ester groups located at different positions along with the linear polyketide-derived backbone. The biosynthesis step comprises the addition of two molecules of tricarballylic esters and one alanine-derived amine to a C-18 polyketide backbone [42]. FBs structural identity has been established, which are similar to sphingosine and are an integral part of cell signaling, growth, and communication [43]. It was believed that fumonisin formation could be controlled by disrupting the biosynthesis of sphingolipids [44]. The biosynthesis process of the toxin has been initiated to illustrate these cellular mechanisms and to design modified analogs $[45,46]$; however, to date, single total synthesis has been achieved by Pereira et al. [47]. There are intra-specific differences in the biosynthesis of fumonosins depending on the environmental conditions, e.g., temperature, the wavelength of light, 
humidity, and media composition for both the Fusarium spp. F. verticillioides and F. proliferatum [48]. Even the responses of strains were found to be different when the plant extracts were added from common hosts of F. proliferatum [49].

\section{Genes Responsible for Fumonisin Production}

Exploring the biosynthesis of trichothecene and fumonisin has revealed the gene cluster fumonisin biosynthetic gene (FUM in Fusarium and Aspergillus) which is responsible for the production of fumonisins, two transport proteins, and a transcription factor [50]. The expression of these genes is co-regulated and related to the FUM genes expression as well; however, it is influenced by ecological conditions [51,52]. The production of fumonisin is dependent on FUM1 which further expresses an enzyme complex known as polyketide synthase that catalyzes the initial step for fumonisin biosynthesis [53]. Furthermore, a positive correlation has been identified between the proportion of FUM1 transcripts being estimated by real-time RT-PCR and the proportion of fumonisins biosynthesized by the F. verticillioides and F. proliferatum species [54]. FUM19 lies at a distance of $35 \mathrm{~kb}$ downstream of the FUM1 gene that expresses an ATP-binding cassette responsible for exporting extracellular fumonisins [51]. Further, the expression of an aminotransferase by FUM8 functions to maintain the biologically active and mature FB1 molecule [55].

A. niger genome has a Fusarium FUM cluster homologue consisting of eleven homologues of the Fusarium genes namely fum1 (polyketide synthase), fum3, fum6, and fum15 (hydroxylase), fum7 (dehydrogenase), fum8 (aminotransferase), fum10 (acyl-CoA synthase), fum13 (carbonyl reductase), fum14 (condensation-domain protein), fum19 (ABC transporter), and fum21 (transcription factor) genes [56,57]. The FUM cluster in the A. niger, also known to have a dehydrogenase gene (sdr1), which is of a short-chain length, is absent in the Fusarium FUM cluster and its role in the process of fumonisin biosynthesis is unknown [56,57]. Further, the Fusarium FUM2 gene is also absent from the A. niger FUM cluster which causes hydroxylation at the C-10 backbone position of fumonisin [58]. The absence of a FUM2 homologue in the $A$. niger cluster has been seen to be consistent with other studies as well revealing that $A$. niger produces fumonisins (FB2, FB4, and FB6) only when it lacks a hydroxyl at C-10 [59-61]. In addition to these, genes like FUG1 and FST1 have been also confirmed to have an important role in fumonisin biosynthesis in F. verticillioides besides their role in maize kernel colonization [62,63]. Furthermore, Niehaus et al. [64] have identified 21 polyketide synthase (PKS) in the genome of the F. proliferatum where PKS3 and PKS11 are predicted to be linked with the biosynthesis of fumonisin.

\section{Occurrence in Food}

The contamination of foods by fumonisin depends on agroclimatic conditions (Table 1). The most commonly infected groups in food are the cereals (rice, wheat, barley, maize, rye, oat, and millet). The FB1 has been reported to contaminate numerous food products like asparagus and garlic [65], barley foods [66], beers [67], dried figs [68], and milk [69]. Maize (Zea mays L.) and maize-based products are one of the most commonly infected foods by FB1 [70]. Maize is used for manufacturing several products like tortillas and tortilla chips, corn flakes and corn starch, popcorn, grits, flour, and oils. However, the contamination by FB1 and FB2 is decreased by 59\% during the manufacturing of tortilla chips from maize flour, while $60 \%$ for flour and $50 \%$ for grits and snack products due to the heat treatment by extrusion [71]. Further, several other products like cornflakes [72], the Portuguese maize bread [73], tea (black and herbal), along with some medicinal plants [74] have also been contaminated by fumonisins. 
Table 1. Occurrence of Fumonisin B1 and FB2 in cereals and cereal-based foods around the world.

\begin{tabular}{|c|c|c|c|c|c|}
\hline Country & Food Matrix & $\begin{array}{c}\text { FB1 (Range, } \\
\mu \mathrm{g} / \mathrm{kg})\end{array}$ & $\begin{array}{c}\text { FB2 (Range, } \\
\mu \mathrm{g} / \mathrm{kg})\end{array}$ & $\begin{array}{l}\text { Detection } \\
\text { Technique }\end{array}$ & Reference \\
\hline UK & Corn & $200-6000$ & - & TLC & [75] \\
\hline $\begin{array}{l}\text { The } \\
\text { Netherlands }\end{array}$ & Corn flour & $40-90$ & - & HPLC & [76] \\
\hline Switzerland & Corn grits & $0-790$ & $0-160$ & HPLC & [77] \\
\hline Turkey & Cornmeal & $250-2660$ & 550 & HPLC & [78] \\
\hline Ghana & Corn & $11-1655$ & $10-770$ & HPLC & [79] \\
\hline Malawi & Corn & 20-115 & 30 & HPLC & [80] \\
\hline Zambia & Corn inbred lines & $20-1420$ & $10-290$ & HPLC & [81] \\
\hline Bahrain & Corn kernel & 25 & - & HPLC & [82] \\
\hline Kenya & Corn kernel & $110-120$ & - & HPLC & [83] \\
\hline Venezuela & Yellow corn & $40-15,050$ & - & HPLC & [84] \\
\hline Korea & Corn for popping & $23-1210$ & - & $\begin{array}{l}\text { direct competitive } \\
\text { (dcELISA) and } \\
\text { HPLC }\end{array}$ & [85] \\
\hline India & Corn seed samples & 133 to 1617 & - & HPLC & [86] \\
\hline Iran & Corn & $10-3980$ & $<10-1180$ & HPLC & [87] \\
\hline Thailand & Corn & $63-18,800$ & $50-1400$ & HPLC & [88] \\
\hline Nepal & Corn kernels & $50-4600$ & $100-5500$ & HPLC & [89] \\
\hline Indonesia & Corn kernels & $51-2440$ & $<376$ & HPLC and GCMS & [90] \\
\hline Argentina & Durum wheat & $10.50-987.20$ & $15-258.50$ & HPLC-MS/MS & [91] \\
\hline Brazil & Wheat & 958-4906 & - & HPLC-FL & [92] \\
\hline Canada & Wheat & - & - & HPLC & [93] \\
\hline $\begin{array}{l}\text { Central } \\
\text { Europe }\end{array}$ & Wheat/wheat bran & - & - & ELISA & [94] \\
\hline China & Wheat flour & $0.30-34.60$ & - & UPLC-MS-MS & [95] \\
\hline France & $\begin{array}{c}\text { Organic Oat, rye and } \\
\text { wheat flakes with maple } \\
\text { syrup }\end{array}$ & $75.70-98.10$ & $62.10-81.10$ & HPLC-MS/MS & [96] \\
\hline Germany & Organic wheat flakes & $20.20-59.80$ & $25.40-41.80$ & HPLC-MS/MS & [96] \\
\hline Iran & Stored wheat samples & 15-155 & $12-86$ & HPLC & [97] \\
\hline Italy & Cereals, whole meal flours & $10-2870$ & $10-420$ & LC-MS & [98] \\
\hline Japan & Wheat & $>10$ & - & LC-ESI-MSMS & [99] \\
\hline Serbia & Wheat & $750-5400$ & - & ELISA & [100] \\
\hline $\begin{array}{l}\text { South } \\
\text { Africa }\end{array}$ & Wheat and wheat products & $1000-30,000$ & - & $\begin{array}{l}\text { TLC, HPLC, } \\
\text { Ms/MS }\end{array}$ & [101] \\
\hline $\begin{array}{l}\text { South } \\
\text { America }\end{array}$ & Wheat/wheat bran & - & - & ELISA-HPLC & [94] \\
\hline $\begin{array}{c}\text { South-East } \\
\text { Asia }\end{array}$ & Wheat/wheat bran & - & - & ELISA-HPLC & [94] \\
\hline $\begin{array}{l}\text { Southern } \\
\text { Europe }\end{array}$ & Wheat/wheat bran & - & - & ELISA-HPLC & [94] \\
\hline Spain & Wheat Gofio & 787.50-1001.40 & $645.20-952.10$ & HPLC-MS/MS & {$[96]$} \\
\hline Syria & Durum wheat & $5-6$ & 12 & HPLC-MS/MS & [102] \\
\hline Tunisia & Wheat-based products & $88.33-184$ & $121-158$ & LC-MS/MS & [103] \\
\hline United States & Wheat & $5-2210$ & $2-249$ & LC-MS & [104] \\
\hline Zimbabwe & Wheat & $2500-6000$ & - & HPLC & [105] \\
\hline
\end{tabular}

\section{Effects on Agriculture and Food}

Annually $25 \%$ of harvested crops are contaminated by mycotoxins, causing huge economic losses to agricultural and industrial commodities. These mycotoxins are stable in nature and do not eliminate during food processing, cooking, baking, roasting, and pasteurization. The meagre agricultural, as well as post-harvest practices like inappropriate drying techniques, handling procedure, packaging materials and methods, and storage and transport conditions, are responsible for the increased risk of fungal growth and fumonisin contamination [106]. Cao et al. [107] investigated the accumulation of fumonisins at different kernel developmental stages as well as during the drying of the kernel of hybrid varieties of white maize. They observed Fusarium (especially F. verticillioides) to be the most prevalent 
genus for growth and contamination as compared to Aspergillus and Penicillium. The lower humidity of kernels favoured damage by insects along with fungal growth and accumulation of fumonisins [107]. The occurrence of fumonisins have been reported in edible plants like onion, garlic, asparagus, and pea seed [108,109]; in other cereals, mainly in wheat $[84,110]$ as well as in crops like sorghum, beans (white, adzuki, mung), barley, soybean, asparagus spears, and figs [111,112]. Besides this, fumonisins have been found to impact the performance of aquatic animals like the Nile tilapia fingerlings and juveniles [113]. Fumonisins affected the hepatic expression of growth hormone receptor (GHR) and insulin like growth factor 1 (IGF-1) in these species, which is an indication that other aquatic animals and plants could also be affected by fumonisins posing a serious threat to food safety and security.

Fumonisins are an important class of mycotoxins produced by F. proliferatum and F. verticillioides along with others such as F. napiforme, F. oxysporum, F. dlamini, F. nygamai and F. anthophilum that are widely distributed, having potential health hazards to humans and animals [9]. These toxins are widely distributed in crops like corn, rice, sorghum, barley, and coffee. The exact causes of ear rot and kernel rot diseases is not well known but may be due to changes in weather such as dry weather followed by warm wet weather during flowering. The damage caused by the insect at the time of maturity allows strains present in nature to enter the ear and kernels. Rain before harvest may intensify the contamination of fumonisins in corn. Sometimes there are substantial amounts of fumonisins present in the non-symptomatic kernels of corn [114]. Yoshizawa et al. [103] reported the occurrence of fumonisins and aflatoxins in eighteen samples of corn in Thailand and found FB1 and FB2 and isolated F. moniliforme and F. proliferatum from the corn grit samples. Studies carried out in the USA reported the presence of FB1 and moniliformin in 34\% of corn samples and 53\% of corn-based food products, respectively [115]. A study in Brazil was conducted (during 2007-2010) to detect fumonisins in corn-based food products and reported that FB1 and FB2 were present in $82 \%$ and $51 \%$ of the examined products, respectively [116]. Contaminations by FB1 and FB2 observed in poultry broiler and feed fatting calves in South Korea [117]. Abdallah et al. [118] found the co-occurrence of FB2 and ochratoxin A and B in the date palm. In Brazil, it was reported that the production of fumonisins by F. verticillioides is found in both symptomatic and asymptomatic grains [119].

Furthermore, a survey was conducted in Japan for aflatoxin, ochratoxin A, and fumonisins contamination using HPLC and LC-MS. Results revealed that peanut butter is contaminated by aflatoxin, while orchratoxin A infection in oatmeal, rye, buckwheat flour, green coffee beans, roasted coffee beans beers, wheat flour, and wine. However, fumonisins were observed in popcorn, frozen corn, corn flasks, and corn grits [120]. Noonim et al. [59] analyzed the aflatoxin and fumonisin contaminations in different samples of Thai dried coffee, and it was noted that no Fusarium spp. were observed; however, A. niger was present in the coffee beans and produced fumonisins along with aflatoxins. A variable range of acetyldeoxynivalenol, deoxynivalenol, neosolaniol, fumonisin B1, and ochratoxin A contaminations were observed in Spanish coffee, and this variation was due to different methods of coffee brewing [121].

\section{Mechanism of Toxicity and Health Effects of Fumonisins}

\subsection{Mechanism of Toxicity}

FB1 predominates in $70 \%$ of the total FBs naturally occurring in infected food and feed samples [122]. FB1 express both acute and chronic symptoms in infected animals. FB1, though being an initiator of cancer, is non-genotoxic [123]. The major organs affected are liver and kidney; however, the severity of infection depends upon the strain and species [124]. The intestine, on the other hand, is a possible target for fumonisin toxicity [125]. FBs contamination has raised higher concern because of their interference with sphingolipid metabolism that ultimately leads to serious health concerns. Fumonisins are also linked to esophagal cancer and defects of the neural tube in humans [126]. Further, FB1 is the major causative agent for porcine pulmonary edema (PPE) [39], the toxicity of the liver and nephron in rodents [127], as well as cancers of the liver and esophagus in humans [128]. 
Franceschi et al. [129] studied the relationship between maize consumption and the risk of cancer of the upper digestive tract in the Pordenone Province in the north-eastern part of Italy. The population of this province has a high incidence of these neoplasms and shows particularly elevated levels of alcohol and tobacco use, in addition to high maize consumption. They observed that there were highly significant associations with frequent intake of maize emerging for oral cancer, pharyngeal cancer, and esophageal cancer. Dragan et al. [130] showed that the FB1 caused renal carcinomas in male rats and liver cancer in female mice. FB1 also induces apoptosis in many kidney cell lines, primary cell cultures, and also in vivo in rat liver and kidney $[130,131]$. Sun et al. [132] reported high contamination of FB1 in the food of the Huaian and Fusui city of China and suggested that FB1 may have a contributing role in human esophageal- and hepatocarcinogenesis. Further, Alizadeh et al. [133] studied 66 samples of both corn and rice from the Golestan province of Iran and observed high levels of FB1 contamination in both corn $(223.66 \mu \mathrm{g} / \mathrm{g})$ and rice $(21.59 \mu \mathrm{g} / \mathrm{g})$. They found a significant relationship between FB1 contamination in rice and the risk of esophageal cancer. Besides this, FB1 was found to be toxic to other cell lines. For example, FB1 triggers dose-dependent apoptosis and necrosis in esophageal carcinoma (SNO) cell lines in humans. Similarly, FB1 inhibited the activity of ceramide (CER) synthase, which is responsible for the acylation of sphinganine (Sa) and the recycling of sphingosine (So). This leads to an increment in the intracellular cytotoxic Sa-compound. Therefore, the variation of $\mathrm{Sa} / \mathrm{So}$ proportions in urine and blood samples may denote the exposure of FBs in several animals; however, this has not been accurately validated [134].

\subsection{Health Effects of Fumonisin}

Equine leucoencephalomalacia first reported in 1891 is now revealed to be caused by consuming fumonisin-contaminated maize [135]. Further, the consumption of maize culture material infected by F. verticillioides [136] is responsible for the occurrence of porcine pulmonary edema (PPE) [30]. Since then, the outbreaks of PPE in the USA have been identified because of fumonisin infection. Further intake of fumonisin-affected diets by pregnant women causes neural tube defects in the developing fetus [126,137]. Sadler et al. [138] reported that FB1 has the potential to inhibit embryonic sphingolipid synthesis, produce embryotoxicity, and block folate transport and has been associated with increased prevalence of cancer and neural tube defects. On the other hand, Missmer et al. [126] reported the prevalence of neural tube defects (NTDs) doubled between 1990-1991 in Mexican-American women because they consume large amounts of corn in the form of tortillas, due to which they may be exposed to high levels of fumonisin. Fumonisin exposure increases the risk of NTDs and a dose above the threshold level may cause fetal death. Similarly, the exposure of fumonisin and its effect on esophageal and liver cancer is rare [132,139]. While no direct evidence of fumonisin hazard is found, its prolonged exposure may lead to cancer and birth defects in humans [140]. Moreover, the co-contamination of foods by fumonisin and aflatoxin has imposed risks of occurrences of outbreaks in southwest Nigeria [140], and the rural areas of Malawi in sub-Saharan Africa [141].

Besides this, the contamination of breast milk by fumonisins has been reported in several studies [142-144]. Recent studies have revealed the relationship between exposure to FBs and growth impairment in children [145-147]. According to Shirima et al. [146], fumonisin exposure negatively impacted child growth among children in Tanzania, which was confirmed based on urinary biomarker levels of fumonisin (UFB1). On the other hand, aflatoxin exposure had no significant impact on child growth. Furthermore, breastfeeding and weaning practices were considered to be associated with growth impairment in children due to exposure to FB1 [147]. The fumonisin carry-over has been observed in cow's milk as well [69]. Therefore, the incidence of fumonisin in human breast milk and its consumption by infants cannot be ignored, as the milk is a crucial part of infants' nutrition [148].

\section{Effects of Processing on Fumonisin}

Fumonisins are known to be comparatively heat-stable and affected only when heated above 150-200 ${ }^{\circ} \mathrm{C}$ during food processing techniques like baking, frying, roasting, or extrusion cooking. 
The degree of reduction in their chemical structure and toxicity depends on the cooking conditions and the composition of the food matrix [149]. However, this reduction could be due to the structural modifications of fumonisins while interacting with other components of food that leads to the conjugate's formation [150]. FB1 interacts with reducing sugars to form strong covalent bonds during heat treatments. For instance, FB1 reacts with D-glucose of corn grits during the extrusion cooking at 160-180 ${ }^{\circ} \mathrm{C}$ and forms a reaction product, $\mathrm{N}$-(carboxymethyl) fumonisin B1 (NCM) [151]. However, the condensation reaction of FB1 and D-glucose forms N-(deoxy-Dfructos-1-yl) FB1 (NDF) [152].

Besides this, the wet milling causes the reduction of fumonisins to some extent in steep water. Further industrial milling processes reduce the fumonisin content significantly such that the fractions obtained (gluten, fiber, germ, and starch) are suitable for animal and human consumption [153]. However, during the dry milling process, there is a negligible reduction in fumonisin content as the fumonisins are embedded in the germ and pericarp in higher concentrations than in the endosperm and its derivatives $[72,154,155]$. Fumonisins are variably distributed in cereals and the fractions depending upon the type of cultivars, agricultural practices, and the method of milling processes $[153,156]$. The toxins might be degraded or modified during the processing of Tortillas at high temperatures and $\mathrm{pH}$ [157]. However, the industrial processing methods like roasting, frying, and extrusion cooking are effective in reducing the fumonisins to significantly low levels [158].

\section{Effects of Environmental Temperature on Fumonisin Production}

The two main factors impacting on the growth of fungus and the production of fumonisin are temperatures and water potential [159]. Therefore, the toxins are predominant in temperate and Mediterranean climatic regions [160-163]. The Mediterranean climate regions experience extreme temperature, rainfall patterns, as well as longer durations of drought. These conditions might lead to variation in the population of mycotoxigenic fungi and the fumonisin production by them which ultimately impacts the control strategies [164]. The infection of maize by F. verticillioides and accumulation of fumonisins is determined by the climatic conditions, insect damage, as well as the plant characteristics. The ear rot infection by F. verticillioides occurs during the flowering stage and is favored by warm and dry conditions; however, both warm and wet conditions following silking have been found to be favorable for disease development [165]. The weather conditions are critical for toxin accumulation during flowering as well as prior to harvesting [166,167]. It has been found that the less rainfall with maximum temperatures of $30-35^{\circ} \mathrm{C}$ during flowering induces disease development [168].

Cendoya et al. [169] evaluated the effect of different levels of temperature and water activity $\left(\mathrm{a}_{\mathrm{W}}\right)$ on the fungal growth and fumonisin biosynthesis in wheat using three strains of $F$. proliferatum. Temperatures of 15,25 , and $30^{\circ} \mathrm{C}$ and $\mathrm{a}_{\mathrm{w}}$ of $0.99,0.98,0.96,0.94,0.92$, and 0.88 were evaluated. They found maximum growth of fumonisins at the highest $\mathrm{a}_{\mathrm{w}}$ of 0.99 at $15^{\circ} \mathrm{C}$ for two strains while for the third strain, the maximum growth was observed at $25{ }^{\circ} \mathrm{C}$ at the same $\mathrm{a}_{\mathrm{w}}$ level. Furthermore, environmental factors like light along with nutrients available impacted the growth of $F$. proliferatum and the production of fumonisin [48,170]. In addition, Li et al. [171] evaluated the impact of $\mathrm{pH}$ levels on the growth of $F$. proliferatum culture. It was found that the toxin production was significantly inhibited in culture maintained at $\mathrm{pH} 5$ compared to the culture at $\mathrm{pH} 10$. However, the acidic $\mathrm{pH} 3-4$, was found to enhance FB1 production by the fungus F. proliferatum [172].

\section{Detection Techniques}

The FB1 presence was detected by the Association of Official Analytical Chemists (AOAC) official method in food and feed samples. The derivatization was done using precolumn with ortho-phthaldialdehyde (OPA) and the detection by chromatographic techniques like HPLC (high-performance liquid chromatography) coupled with a fluorescence detector (HPLC-FLD). However, the drawback of this method is the use of high sample size (around $50 \mathrm{~g}$ ), more extraction solvent (methanol:water), and solid-phase extraction (SPE) cartridges [173]. Therefore, methods like QuEChERS (Quick, Easy, Cheap, Effective, Rugged, and Safe) proved to be ideal for the detection of 
FB1 [174-176]. Some of the commonly used techniques for fumonisin extractions include: (i) solid-liquid extraction (SLE) [177-180], (ii) liquid-liquid extraction (LLE) [181,182], (iii) matrix solid-phase dispersion (MSPD) [87,183,184], and (iv) dispersive liquid-liquid microextraction (DLLME) [185]. Recently, it was observed that the extraction yields were higher in finer flours indicating the importance of sample particle size on the recovery of fumonisins [11].

The traditional analytical methods to detect and quantify fumonisin include HPLC or UPLC (ultra-performance liquid chromatography) coupled with detectors such as UV-Vis spectrophotometric [186], fluorescence [187,188], and mass spectrometry (MS) [176,189-191]; liquid chromatography-mass spectrometry (LC-MS), and thin-layer chromatography (TLC) [192-194]. As these methods are expensive, tedious, and time-consuming [195], other advanced methods like the detection of mycotoxins producing fungi, enzyme-linked immunosorbent assay (ELISA), surface plasmon resonance (SPR), lateral flow immunoassay (LFI), immunosensors, electronic nose, and hyperspectral imaging are found to be more efficient $[194,196]$. Fumonisins producing genes have been amplified by PCR to detect Fusarium species in freshly harvested maize kernels [197]. PCR-based methods are used for the detection of mycotoxins producing fungal genera Fusarium, Aspergillus, and, Penicillium $[198,199]$.

Recently, Nagaraj et al. [196] used a multiplex PCR technique to detect fumonisin producing F. verticillioides strains. ELISA coupled with PCR, i.e., PCR-ELISA by Omor et al. [200] for the detection of $F$. verticillioides based on the FUM21 gene in corn. In addition to this, a highly sensitive indirect competitive enzyme-linked immunosorbent assay (icELISA) and gold nanoparticle-based gray imaging quantification immunoassay (GNPs-GI) has been developed to detect FB1 in agricultural products [201]. Another important and non-destructive way of identifying toxigenic fungi in maize is by the application of hyperspectral imaging processes [202,203]. Besides this, the color-encoded lateral flow immunoassay (LFIA) has emerged as a leading technique for simultaneous detection of aflatoxin B1 and type-B fumonisins in a single test line [204]. Nowadays, electrochemical immunosensors are employed for rapid and sensitive detection of FB1 [205]. Furthermore, a rapid and ultrasensitive molecularly imprinted photoelectrochemical (MIP-PEC) sensing technique has been recently developed to measure FB1 [206].

\section{Masked Mycotoxins as a major concern in detection}

The masked mycotoxins issue was initially seen during the mid-1980s due to several mysterious cases of mycotoxicosis occurrence; however, the symptoms of mycotoxins in affected animals did not connect with the low mycotoxins content detected in their feed. At the same time, the metabolic biotransformation of deoxynivalenol (DON) to the less toxic derivatives in planta was first reported to appear in corn inoculated with F. graminerium [207] and also in naturally infected winter wheat [208]. In vivo studies for masked mycotoxins were carried out in pig and reported that zearalenone-14-glucoside was decomposed during the digestion process and zearalenone (ZEN) and zearalenol (ZEL) were detected in urinary and fecal metabolites [209].

During infection in plants, the mycotoxins produced by fungi are modified by plant enzymes and often conjugated to more polar substances, like sugars. These form of toxins are often less toxic metabolites stored in the vacuole in the soluble form or bound to macromolecules and are not detectable during routine analysis processes; therefore, referred to as masked mycotoxins [210]. These mycotoxins may not be a homogeneous group of contaminants but somewhat a complex mixture of different plant metabolites of various classes of mycotoxins and they are overall termed as the 'maskedome' [211]. Detection of masked mycotoxins is difficult as they change the physiological properties of their molecules leading to modified chromatographic behavior [212]. Due to less detectability, these toxins are a serious concern for food safety and these toxins may be converted back to the parent toxin forms during the food digestion process [213]. De Boevre et al. [214] analyzed cereal-based food products and raw feed materials for the presence of mycotoxins including deoxynivalenol, 3-acetyldeoxynivalenol, 15 -acetyldeoxynivalenol, zearalenone, $\alpha$-zearalenol ( $\alpha$-ZEL), $\beta$-zearalenol, and their respective 
masked forms like $\alpha$-zearalenol-1-3glucoside, zearalenone-4-glucoside, $\alpha$-zearalenone-4-glucoside, $\beta$-zearalenone-4-glucoside, and zearalenone-4-sulfate in fiber-enriched bread, bran-enriched bread, cornflakes, popcorn, and oatmeal. Binder et al. [215] evaluated the absorption, distribution, metabolism, and excretion (ADME) of plant (ZEN-14-Glc, ZEN-16-Glc) and fungal (ZEN-14-S) ZEN metabolites in pigs and found that the total amounts of ZEN-14-GlcA, ZEN, and $\alpha$-ZEL were excreted into urine after 0-48 hours of administration.

\section{Degradation Kinetics}

The degradation of FB1 was first revealed by Duvick et al. [216] to occur by microbes like Exophiala spinifera, Rhinocladiella atrovirens, and Sphingomonas or Xanthomonas having the capacity to metabolize FB1. These microbes were isolated from various tissues of maize. Further, the fumonisin metabolism by E. spinifera and the bacterium (deposited as ATCC55552 with the American Type Culture Collection) was studied by radiochemical and chromatographic (e.g., thin layer chromatography, TLC) methods. The initial two steps of biodegradation of FB1 were revealed to be due to de-esterification by a carboxylesterase releasing two tricarballylic acid (TCA) moieties leading to the formation of hydrolyzed FB1 (HFB1). The bacterial strain ATCC55552 further metabolized 14C-FB1 with the release of 14 molecules of $\mathrm{CO}_{2}$. However, E. spinifera could not further metabolize the TCA moieties. Blackwell et al. [217] later studied the oxidative deamination process of HFB1 by E. spinifera through TLC and mass spectrometry. They found that the HFB1 gets converted to Nacetyl HFB1 and 2-oxo-12,16-dimethyl-3,5,10,14,15-icosanepentol hemiketal. A cluster of genes in the bacterium ATCC55552 responsible for the degradation of fumonisin is mentioned in a patent, WO 00/04158 by Duvick et al. [218].

FB1 can be degraded to the less toxic form of hydrolyzed FB1 (HFB1) by an enzymatic process which could be used to reduce intestinal inflammation in pigs [219]. Further, the gene that catalyzes the oxidative deamination process of HFB1 in E. spinifera was revealed; however, the responsible enzyme for the deamination reaction is still unknown [218]. Later, Benedetti et al. [220] screened and isolated a bacterium related to the Delftia/Comamonas group (known as NCB 1492) from the soil. It was able to hydrolyze and deaminate FB1, but still, the sequences of the responsible genes are unknown. A year before, Sphingomonas sp. MTA144 was shown to have fumonisin degrading activity [221]. Further, Heinl et al. [222] identified two genes (carboxylesterase and aminotransferase) having prominent fumonisin-degrading activity. In addition to this, essential oils from plants were found to inhibit as well as degrade FB1 for example anise, camphor, cinnamon, citral, clove, eucalyptus, Litsea cubeba, and spearmint $[223,224]$.

\section{Management and Control Strategies}

\subsection{Management and Control using Agricultural Practices}

As the crop plants like maize are infected by fumonisins during their growth in fields [225], the implementation of good agricultural practices (GAP), good storage practices (GSP), and good manufacturing practices (GMP) can mitigate the fumonisin contamination [226]. Harvesting the crop at earlier stages could be one of the strategies to control fumonisin contamination [227]; however, this cannot be applied to crops that need to be harvested at full maturity. Instead, the early harvest can be done for forage maize to increase the digestibility of silage. These practices require careful study as the farmers prefer a delayed harvest because of advancement in technologies. For instance, the use of kernel processors during forage harvesting leads to the production of digestible silage from maize when harvested at later stages [228].

Recently, the Codex Alimentarius Commission has set maximum levels of fumonisin at $4000 \mu \mathrm{g} /$ $\mathrm{kg}$ and $2000 \mu \mathrm{g} / \mathrm{kg}$, respectively for raw maize and for maize flour and meal which have been implemented in South Africa. However, the lowering of fumonisin exposure in subsistence farmers need an integrated approach, and this cannot be solely achieved by regulatory measures [229]. Besides 
these approaches, the use of nanotechnology and genetic engineering should be encouraged in the field of agriculture to develop resistant varieties of crops to get rid of Fusarium infection and FB contamination. The creation of drought and insect-resistant crops can also play a significant role in the fumonisin control as these factors are responsible, in one or the other way, for the fungal infection [230]. In addition to this, educating the farmers about the importance of drying and sorting out of the contaminated kernels from the crops can manage and control the risk of infection to some extent [231]. The in vitro study of combinations of fungicides (fludioxonil + metalaxyl-M) showed that it was not sufficient in the growth inhibition of $F$. verticillioides and even the increase in the production of FB1 by their strains [232]. A similar study also showed that these fungicides inhibit the growth and extracellular material formation but enhance the sporulation and fumonisin production in liquid culture of $F$. verticillioides [233]. Masiello et al. [234] reported that prothioconazole and thiophanate-methyl were effective in reducing the F. graminearum ( $52 \%$ and $48 \%$ ) and F. proliferatum contamination ( $44 \%$ and $27 \%$ ) under the field trial.

Fumonisin production and Fusarium growth are the result of interactions with various biotic and abiotic factors. In the case of abiotic factor temperature, water stress was the most significant environmental factor which influenced the fumonisin production and Fusarium growth. Several other stress conditions such as osmotic stress, $\mathrm{pH}$, and fungicides were reported for the production mycotoxins $[235,236]$. F. verticillioides isolates were found to exhibit better performance at higher temperatures and under water stress conditions in comparison to F. proliferatum, another fumonisinproducing species. Marin et al. [237] suggested that environmental conditions leading to water stress (drought) might result in an increased risk of fumonisin contamination of maize caused by F. verticillioides. Drought stress and excess irrigation favor Fusarium infection. Drought stress should be avoided during the period of wheat seed development and maturation [238]. Excess moisture during the flowering seasons and early grain-fill periods also supports the Fusarium infection and moisture also increases the DON contamination [239]. Fungicide treatments were found to be effective against wheat Fusarium infection and DON contaminations [240,241]. Azole fungicides were found to be effective in the reduction of DON and other emerging and modified mycotoxins [242]. Therefore, an integrated approach, involving good agricultural management practices, hazard analysis, and critical control point production, storage management along with selected biologically based treatments, and mild chemical and physical treatments could reduce the fumonisin contamination effectively [243].

\subsection{Management and Control using Mycotoxin Binder}

Mycotoxin binders or adsorbents are substances that bind to mycotoxins and prevent them from being absorbed through the gut and prevent their entrance into the blood circulation. The mycotoxin binders can be helpful and utilized when other preventive measures fail against molds and mycotoxins [244]. The main aim of mycotoxin binders is to prevent the absorption of the mycotoxins from the intestinal tract of animals by absorbing the toxin to their surface. These binders may be organic or inorganic in nature, such as clay and yeast derived products, respectively [245]. However, mycotoxin modifiers are used to alter the chemical structure of mycotoxins and reduce their toxicity. These are microbiological in origin containing whole bacterial and yeast culture and specifically extracted compound such as enzymes [246]. In the field during harvesting of the crop, the production of mycotoxins can be reduced by choosing varieties that are adapted to the growing area and have resistance to fungal diseases. Mycotoxin production can also be reduced in the field by proper irrigation and balanced fertilizer applications [247]. These binders bind to the mycotoxins strong enough to prevent toxic interactions with the consuming animals and their absorption across the digestive tract. Potential absorbent materials include activated carbon, aluminosilicates (bentonite, clay, montmorillonite, zeolite, pollyosilicates etc.), complex indigestible carbohydrates (Cellulose, polysaccharides in the cell wall of yeast and bacteria such as glucomannans, petidoglycans) and other synthetic polymers such as cholestryamine and polyvinylpyrrolidone and derivatives [247]. De Mil et al. [248] characterized 27 feed additives marketed as mycotoxin binders and screened them 
for their in vitro zearalenone (ZEN) adsorption. Recent studies showed that the addition of the commercial toxin binders to the aflatoxin B1 (AFB1) containing diets reduced the adverse effects of AFB1 and could be helpful as a solution to the aflatoxicosis problem in young broiler chicks [249].

\section{Conclusion}

The contamination of food and feed by fumonisin is a serious threat for disease outbreaks worldwide. The various techniques ranging from physical to biochemical as well as genetic engineering can be utilized in an efficient manner to mitigate fumonisin contamination of foods. However, a major issue of concern lies with the development of fungal and insect resistant crops to combat the fungal infection and fumonisin contamination. The naturally occurring soil microorganisms have been reported to have an immense capability of degrading and reducing the biosynthesis of fumonisins and its contamination in various agricultural crops. Moreover, the application of nanotechnology and genetic engineering should be given more emphasis to develop resistant varieties of crops and ensure the safety and quality of food for future generations.

Author Contributions: P.K. conceived and designed the manuscript; D.K.M., M.K., and P.K. wrote the manuscript; K.E.L. and S.D. helped in the editing of the manuscript; P.K. and S.G.K. critically reviewed the manuscript and did the required editing.

Funding: This work was supported by the Sunforce Inc. Republic of Korea.

Acknowledgments: All authors are highly grateful to the authority of the respective department and Institution for their support in doing this research. Author (P.K.) would like to thank the DST-SERB (file no ECR/2017/001143) and DBT-Twinning (No. BT/PR24741/NER/95/659/2017) for their financial support. This work was supported by the Sunforce Inc. Republic of Korea.

Conflicts of Interest: The authors declare no conflict of interest.

\section{References}

1. Rheeder, J.P.; Marasas, W.F.; Vismer, H.F. Production of fumonisin analogs by Fusarium species. Appl. Environ. Microbiol. 2002, 68, 2101-2105. [CrossRef] [PubMed]

2. Astoreca, A.; Magnoli, C.; Barberis, C.; Chiacchiera, S.; Combina, M.; Dalcero, A. Ochratoxin a production in relation to ecophysiological factors by Aspergillus section Nigri strains isolated from different substrates in Argentina. Sci. Total Environ. 2007, 388, 16-23. [CrossRef] [PubMed]

3. Astoreca, A.; Magnoli, C.; Ramirez, M.L.; Combina, M.; Dalcero, A. Water activity and temperature effects on growth of Aspergillus niger, A. awamori and A. carbonarius isolated from different substrates in Argentina. Int. J. Food Microbiol. 2007, 119, 314-318. [CrossRef] [PubMed]

4. Frisvad, J.C.; Smedsgaard, J.; Samson, R.A.; Larsen, T.O.; Thrane, U. Fumonisin B2 production by Aspergillus niger. J. Agric. Food Chem. 2007, 55, 9727-9732. [CrossRef] [PubMed]

5. Mogensen, J.M.; Frisvad, J.C.; Thrane, U.; Nielsen, K.F. Production of fumonisin B2 and B4 by Aspergillus niger on grapes and raisins. J. Agric. Food Chem. 2009, 58, 954-958. [CrossRef] [PubMed]

6. Kumar, P.; Mahato, D.K.; Kamle, M.; Mohanta, T.K.; Kang, S.G. Aflatoxins: A global concern for food safety, human health and their management. Front. Microbiol. 2017, 7, 2170. [CrossRef]

7. Dall'Asta, C.; Battilani, P. Fumonisins and their modified forms, a matter of concern in future scenario? World Mycotoxin J. 2016, 9, 727-739. [CrossRef]

8. Cendoya, E.; Chiotta, M.L.; Zachetti, V.; Chulze, S.N.; Ramirez, M.L. Fumonisins and fumonisin-producing Fusarium occurrence in wheat and wheat by products: A review. J. Cereal Sci. 2018, 80, 158-166. [CrossRef]

9. Braun, M.S.; Wink, M. Exposure, occurrence, and chemistry of fumonisins and their cryptic derivatives. Compr. Rev. Food Sci. Food Saf. 2018, 17, 769-791. [CrossRef]

10. Marasas, W.F. Fumonisins in Food; Springer: Berlin/Heidelberg, Germany, 1996.

11. Damiani, T.; Righetti, L.; Suman, M.; Galaverna, G.; Dall'Asta, C. Analytical issue related to fumonisins: A matter of sample comminution? Food Control 2019, 95, 1-5. [CrossRef]

12. Shephard, G. Chromatographic determination of the fumonisin mycotoxins. J. Chromatogr. A 1998, 815, 31-39. [CrossRef] 
13. Corrêa, J.A.F.; Orso, P.B.; Bordin, K.; Hara, R.V.; Luciano, F.B. Toxicological effects of fumonisin B1 in combination with other Fusarium toxins. Food Chem. Toxicol. 2018, 121, 483-494. [CrossRef] [PubMed]

14. Garrido, C.; Pezzani, C.H.; Pacin, A. Mycotoxins occurrence in Argentina's maize (Zea mays L.), from 1999 to 2010. Food Control. 2012, 25, 660-665. [CrossRef]

15. Vargas, E.; Preis, R.; Castro, L.; Silva, C. Co-occurrence of aflatoxins B 1, B 2, G 1, G 2, zearalenone and fumonisin B 1 in Brazilian corn. Food Addit. Contam. 2001, 18, 981-986. [CrossRef] [PubMed]

16. Wang, Y.; Liu, S.; Zheng, H.; He, C.; Zhang, H. T-2 toxin, zearalenone and fumonisin B1 in feedstuffs from China. Food Addit. Contam. 2013, 6, 116-122. [CrossRef] [PubMed]

17. Gutleb, A.; Caloni, F.; Giraud, F.; Cortinovis, C.; Pizzo, F.; Hoffmann, L.; Bohn, T.; Pasquali, M. Detection of multiple mycotoxin occurrences in soy animal feed by traditional mycological identification combined with molecular species identification. Toxicol. Rep. 2015, 2, 275-279. [CrossRef] [PubMed]

18. Almeida, I.; Martins, H.M.; Santos, S.; Costa, J.M.; Bernardo, F. Co-occurrence of mycotoxins in swine feed produced in Portugal. Mycotoxin Res. 2011, 27, 177-181. [CrossRef] [PubMed]

19. Cano-Sancho, G.; Ramos, A.J.; Marín, S.; Sanchis, V. Presence and co-occurrence of aflatoxins, deoxynivalenol, fumonisins and zearalenone in gluten-free and ethnic foods. Food Control 2012, 26, 282-286. [CrossRef]

20. Kamala, A.; Ortiz, J.; Kimanya, M.; Haesaert, G.; Donoso, S.; Tiisekwa, B.; De Meulenaer, B. Multiple mycotoxin co-occurrence in maize grown in three agro-ecological zones of Tanzania. Food Control. 2015, 54, 208-215. [CrossRef]

21. Tansakul, N.; Jala, P.; Laopiem, S.; Tangmunkhong, P.; Limsuwan, S. Co-occurrence of five Fusarium toxins in corn-Dried Distiller's Grains with Solubles in Thailand and comparison of ELISA and LC-MS/MS for fumonisin analysis. Mycotoxin Res. 2013, 29, 255-260. [CrossRef]

22. Chu, F.S.; Li, G.Y. Simultaneous occurrence of fumonisin B1 and other mycotoxins in moldy corn collected from the People's Republic of China in regions with high incidences of esophageal cancer. Appl. Environ. Microbiol. 1994, 60, 847-852. [PubMed]

23. Gelderblom, W.; Jaskiewicz, K.; Marasas, W.; Thiel, P.; Horak, R.; Vleggaar, R.; Kriek, N. Fumonisins-novel mycotoxins with cancer-promoting activity produced by Fusarium moniliforme. Appl. Environ. Microbiol. 1988, 54, 1806-1811. [PubMed]

24. Carlson, D.B.; Williams, D.E.; Spitsbergen, J.M.; Ross, P.F.; Bacon, C.W.; Meredith, F.I.; Riley, R.T. Fumonisin $\mathrm{B} 1$ promotes aflatoxin B1 and N-methyl-N'-nitro-nitrosoguanidine-initiated liver tumors in rainbow trout. Toxicol. Appl. Pharmacol. 2001, 172, 29-36. [CrossRef] [PubMed]

25. Qian, G.; Tang, L.; Lin, S.; Xue, K.S.; Mitchell, N.J.; Su, J.; Gelderblom, W.C.; Riley, R.T.; Phillips, T.D.; Wang, J.-S. Sequential dietary exposure to aflatoxin B1 and fumonisin B1 in F344 rats increases liver preneoplastic changes indicative of a synergistic interaction. Food Chem. Toxicol. 2016, 95, 188-195. [CrossRef] [PubMed]

26. Xue, K.S.; Qian, G.; Lin, S.; Su, J.; Tang, L.; Gelderblom, W.C.; Riley, R.T.; Phillips, T.D.; Wang, J.-S. Modulation of pre-neoplastic biomarkers induced by sequential aflatoxin B1 and fumonisin B1 exposure in F344 rats treated with UPSN clay. Food Chem. Toxicol. 2018, 114, 316-324. [CrossRef] [PubMed]

27. International Agency for Research on Cancer (IARC), World Health Organisation (WHO). Fumonisin B1. In IARC Monographs on the Evaluation of Carcinogenic Risks to Humans, Some Traditional Herbal Medicines, Some Mycotoxins, Naphthalene and Styrene; IARC Press: Lyon, France, 2002; Volume 82, pp. 301-366.

28. Joint FAO WHO Expert Committee on Food Additives, World Health Organization. Safety evaluation of certain food additives and contaminants: Prepared by the Seventy fourth meeting of the Joint FAO/WHO Expert Committee on Food Additives (JECFA). Available online: https:/apps.who.int/iris/bitstream/handle/ 10665/171781/9789240693982_eng.pdf;jsessionid=79EFFBD803B75293027EDA351F998A18? sequence=3 (accessed on 7 June 2019).

29. Burgess, L. General ecology of the fusaria. In Fusarium: Diseases, Biology, and Taxonomy; Nelson, P.E., Toussoun, T.A., Cook, R.J., Eds.; Pennsylvania State University Press: University Park, PA, USA, 1981; pp. 225-235.

30. Marasas, W. Discovery and occurrence of the fumonisins: A historical perspective. Environ. Health Perspect. 2001, 109, 239-243. [PubMed]

31. Gullino, M.L.; Minuto, A.; Gilardi, G.; Garibaldi, A. Efficacy of azoxystrobin and other strobilurins against Fusarium wilts of carnation, cyclamen and Paris daisy. Crop. Prot. 2002, 21, 57-61. [CrossRef]

32. Booth, C. The genus Fusarium. Fusarium; CAB, 1971. Available online: http://www.mycobank.org/BioloMICS. aspx?TableKey=14682616000000061\&Rec=744\&Fields=All (accessed on 7 June 2019). 
33. Vujanovic, V.; St-Arnaud, M.; Barabé, D.; Thibeault, G. Viability testing of orchid seed and the promotion of colouration and germination. Ann. Bot. 2000, 86, 79-86. [CrossRef]

34. Alabouvette, C.; Lemanceau, P.; Steinberg, C. Recent advances in the biological control of Fusarium wilts. Pestic. Sci. 1993, 37, 365-373. [CrossRef]

35. Louvet, J.; Rouxel, F.; Alabouvette, C. Recherches sur la résistance des sols aux maladies. I. Mise en évidence de la nature microbiologique de la résistance d'un sol au développement de la fusariose vasculaire du melon. Ann. Phytopathol. 1976, 8, 425-436.

36. Coleman, J.J. The Fusarium solani species complex: Ubiquitous pathogens of agricultural importance. Mol. Plant Pathol. 2016, 17, 146-158. [CrossRef] [PubMed]

37. Chulze, S. Strategies to reduce mycotoxin levels in maize during storage: A review. Food Addit. Contam. 2010, 27, 651-657. [CrossRef]

38. Ross, P.F.; Rice, L.G.; Osweiler, G.D.; Nelson, P.E.; Richard, J.L.; Wilson, T.M. A review and update of animal toxicoses associated with fumonisin-contaminated feeds and production of fumonisins by Fusarium isolates. Mycopathologia 1992, 117, 109-114. [CrossRef] [PubMed]

39. Harrison, L.R.; Colvin, B.M.; Greene, J.T.; Newman, L.E.; Cole Jr, J.R. Pulmonary edema and hydrothorax in swine produced by fumonisin B1, a toxic metabolite of Fusarium moniliforme. J. Vet. Diagn. Investig. 1990, 2, 217-221. [CrossRef] [PubMed]

40. Voss, K.A.; Plattner, R.D.; Riley, R.T.; Meredith, F.I.; Norred, W.P. In vivo effects of fumonisin B 1-producing and fumonisin B 1-nonproducing Fusarium moniliforme isolates are similar: Fumonisins B 2 and B 3 cause hepato-and nephrotoxicity in rats. Mycopathologia 1998, 141, 45-58. [CrossRef] [PubMed]

41. Jones, C.; Ciacci-Zanella, J.R.; Zhang, Y.; Henderson, G.; Dickman, M. Analysis of fumonisin B1-induced apoptosis. Environ. Health Perspect. 2001, 109 (Suppl. 2), 315-320. [CrossRef]

42. Burgess, K.M.; Renaud, J.B.; McDowell, T.; Sumarah, M.W. Mechanistic insight into the biosynthesis and detoxification of fumonisin mycotoxins. ACS Chem. Biol. 2016, 11, 2618-2625. [CrossRef]

43. Chandrasekhar, S.; Sreelakshmi, L. Formal synthesis of fumonisin B1, a potent sphingolipid biosynthesis inhibitor. Tetrahedron Lett. 2012, 53, 3233-3236. [CrossRef]

44. Wang, E.; Norred, W.; Bacon, C.; Riley, R.; Merrill, A.H. Inhibition of sphingolipid biosynthesis by fumonisins. Implications for diseases associated with Fusarium moniliforme. J. Biol. Chem. 1991, 266, 14486-14490.

45. Gurjar, M.K.; Rajendran, V.; Rao, B.V. Chiron approach towards a potent toxin fumonisin B1 backbone: Synthesis of its hexaacetate derivative. Tetrahedron Lett. 1998, 39, 3803-3806. [CrossRef]

46. Oikawa, H.; Yamawaki, D.; Kagawa, T.; Ichihara, A. Total synthesis of AAL-toxin TA1. Tetrahedron Lett. 1999, 40, 6621-6625. [CrossRef]

47. Pereira, C.L.; Chen, Y.-H.; McDonald, F.E. Total synthesis of the sphingolipid biosynthesis inhibitor fumonisin B1. J. Am. Chem. Soc. 2009, 131, 6066-6067. [CrossRef] [PubMed]

48. Fanelli, F.; Schmidt-Heydt, M.; Haidukowski, M.; Geisen, R.; Logrieco, A.; Mulè, G. Influence of light on growth, fumonisin biosynthesis and FUM1 gene expression by Fusarium proliferatum. Int. J. Food Microbiol. 2012, 153, 148-153. [CrossRef] [PubMed]

49. Stępień, Ł.; Waśkiewicz, A.; Wilman, K. Host extract modulates metabolism and fumonisin biosynthesis by the plant-pathogenic fungus Fusarium proliferatum. Int. J. Food Microbiol. 2015, 193, 74-81. [CrossRef]

50. Alexander, N.J.; Proctor, R.H.; McCormick, S.P. Genes, gene clusters, and biosynthesis of trichothecenes and fumonisins in Fusarium. Toxin Rev. 2009, 28, 198-215. [CrossRef]

51. Proctor, R.H.; Brown, D.W.; Plattner, R.D.; Desjardins, A.E. Co-expression of 15 contiguous genes delineates a fumonisin biosynthetic gene cluster in Gibberella moniliformis. Fungal Genet. Biol. 2003, 38, 237-249. [CrossRef]

52. Desjardins, A.; Proctor, R. Molecular biology of Fusarium mycotoxins. Int. J. Food Microbiol. 2007, 119, 47-50. [CrossRef]

53. Bojja, R.S.; Cerny, R.L.; Proctor, R.H.; Du, L. Determining the biosynthetic sequence in the early steps of the fumonisin pathway by use of three gene-disruption mutants of Fusarium verticillioides. J. Agric. Food Chem. 2004, 52, 2855-2860. [CrossRef]

54. López-Errasquín, E.; Vázquez, C.; Jiménez, M.; González-Jaén, M.T. Real-time RT-PCR assay to quantify the expression of FUM1 and FUM19 genes from the fumonisin-producing Fusarium verticillioides. J. Microbiol. Methods 2007, 68, 312-317. [CrossRef]

55. Seo, J.-A.; Proctor, R.H.; Plattner, R.D. Characterization of four clustered and coregulated genes associated with fumonisin biosynthesis in Fusarium verticillioides. Fungal Genet. Biol. 2001, 34, 155-165. [CrossRef] 
56. Baker, S.E. Aspergillus niger genomics: Past, present and into the future. Med. Mycol. 2006, 44, S17-S21. [CrossRef] [PubMed]

57. Pel, H.J.; De Winde, J.H.; Archer, D.B.; Dyer, P.S.; Hofmann, G.; Schaap, P.J.; Turner, G.; De Vries, R.P.; Albang, R.; Albermann, K. Genome sequencing and analysis of the versatile cell factory Aspergillus niger CBS 513.88. Nat. Biotechnol. 2007, 25, 221-231. [CrossRef]

58. Proctor, R.H.; Plattner, R.D.; Desjardins, A.E.; Busman, M.; Butchko, R.A. Fumonisin production in the maize pathogen Fusarium verticillioides: Genetic basis of naturally occurring chemical variation. J. Agric. Food Chem. 2006, 54, 2424-2430. [CrossRef] [PubMed]

59. Noonim, P.; Mahakarnchanakul, W.; Nielsen, K.F.; Frisvad, J.C.; Samson, R.A. Fumonisin B2 production by Aspergillus niger in Thai coffee beans. Food Addit. Contam. 2009, 26, 94-100. [CrossRef]

60. Mansson, M.; Klejnstrup, M.L.; Phipps, R.K.; Nielsen, K.F.; Frisvad, J.C.; Gotfredsen, C.H.; Larsen, T.O. Isolation and NMR characterization of fumonisin B2 and a new fumonisin B6 from Aspergillus niger. J. Agric. Food Chem. 2009, 58, 949-953. [CrossRef] [PubMed]

61. Susca, A.; Proctor, R.H.; Butchko, R.A.; Haidukowski, M.; Stea, G.; Logrieco, A.; Moretti, A. Variation in the fumonisin biosynthetic gene cluster in fumonisin-producing and nonproducing black aspergilli. Fungal Genet. Biol. 2014, 73, 39-52. [CrossRef]

62. Kim, H.; Woloshuk, C.P. Functional characterization of fst1 in Fusarium verticillioides during colonization of maize kernels. Mol. Plant Microbe Interact. 2011, 24, 18-24. [CrossRef]

63. Ridenour, J.B.; Bluhm, B.H. The novel fungal-specific gene FUG1 has a role in pathogenicity and fumonisin biosynthesis in Fusarium verticillioides. Mol. Plant Pathol. 2017, 18, 513-528. [CrossRef]

64. Niehaus, E.-M.; Münsterkötter, M.; Proctor, R.H.; Brown, D.W.; Sharon, A.; Idan, Y.; Oren-Young, L.; Sieber, C.M.; Novák, O.; Pěnčík, A. Comparative "omics" of the Fusarium fujikuroi species complex highlights differences in genetic potential and metabolite synthesis. Genome Biol. Evol. 2016, 8, 3574-3599. [CrossRef]

65. Seefelder, W.; Gossmann, M.; Humpf, H.-U. Analysis of fumonisin B1 in Fusarium proliferatum-infected asparagus spears and garlic bulbs from Germany by liquid chromatography- electrospray ionization mass spectrometry. J. Agric. Food Chem. 2002, 50, 2778-2781. [CrossRef]

66. Park, J.; Kim, E.; Shon, D.; Kim, Y. Natural co-occurrence of aflatoxin B1, fumonisin B1 and ochratoxin A in barley and corn foods from Korea. Food Addit. Contam. 2002, 19, 1073-1080. [CrossRef] [PubMed]

67. Kawashima, L.M.; Vieira, A.P.; Soares, L.M.V. Fumonisin B1 and ochratoxin A in beers made in Brazil. Food Sci. Technol. 2007, 27, 317-323. [CrossRef]

68. Heperkan, D.; Güler, F.K.; Oktay, H. Mycoflora and natural occurrence of aflatoxin, cyclopiazonic acid, fumonisin and ochratoxin A in dried figs. Food Addit. Contam. Part A 2012, 29, 277-286. [CrossRef] [PubMed]

69. Gazzotti, T.; Lugoboni, B.; Zironi, E.; Barbarossa, A.; Serraino, A.; Pagliuca, G. Determination of fumonisin B1 in bovine milk by LC-MS/MS. Food Control 2009, 20, 1171-1174. [CrossRef]

70. Stępień, Ł.; Koczyk, G.; Waśkiewicz, A. Genetic and phenotypic variation of Fusarium proliferatum isolates from different host species. J. Appl. Genet. 2011, 52, 487-496. [CrossRef] [PubMed]

71. Scudamore, K.; Scriven, F.; Patel, S. Fusarium mycotoxins in the food chain: Maize-based snack foods. World Mycotoxin J. 2009, 2, 441-450. [CrossRef]

72. Castells, M.; Marín, S.; Sanchis, V.; Ramos, A.J. Distribution of fumonisins and aflatoxins in corn fractions during industrial cornflake processing. Int. J. Food Microbiol. 2008, 123, 81-87. [CrossRef] [PubMed]

73. Lino, C.; Silva, L.; Pena, A.; Fernández, M.; Mañes, J. Occurrence of fumonisins B1 and B2 in broa, typical Portuguese maize bread. Int. J. Food Microbiol. 2007, 118, 79-82. [CrossRef] [PubMed]

74. Omuttang, G.Z.; Yaziciogilu, D. Determination of fumonisins B1 and B2 in herbal tea and medicinal plants in Turkey by high-performance liquid chromatography. J. Food Prot. 2004, 67, 1782-1786.

75. Preis, R.; Vargas, E. A method for determining fumonisin B1 in corn using immunoaffinity column clean-up and thin layer chromatography/densitometry. Food Addit. Contam. 2000, 17, 463-468. [CrossRef] [PubMed]

76. De Nijs, M.; Sizoo, E.; Vermunt, A.; Notermans, S.; Van Egmond, H. The occurrence of fumonisin B1 in maize-containing foods in the Netherlands. Food Addit. Contam. 1998, 15, 385-388. [CrossRef] [PubMed]

77. Pittet, A.; Parisod, V.; Schellenberg, M. Occurrence of fumonisins B1 and B2 in corn-based products from the Swiss market. J. Agric. Food Chem. 1992, 40, 1352-1354. [CrossRef]

78. Omurtag, G.Z. Determination of fumonisin B1 and B2 in corn and corn-based products in Turkey by high-performance liquid chromatography. J. Food Prot. 2001, 64, 1072-1075. [CrossRef] [PubMed] 
79. Kpodo, K.; Thrane, U.; Hald, B. Fusaria and fumonisins in maize from Ghana and their co-occurrence with aflatoxins. Int. J. Food Microbiol. 2000, 61, 147-157. [CrossRef]

80. Doko, M.B.; Canet, C.; Brown, N.; Sydenham, E.W.; Mpuchane, S.; Siame, B.A. Natural co-occurrence of fumonisins and zearalenone in cereals and cereal-based foods from Eastern and Southern Africa. J. Agric. Food Chem. 1996, 44, 3240-3243. [CrossRef]

81. Doko, M.B.; Rapior, S.; Visconti, A.; Schjoth, J.E. Incidence and levels of fumonisin contamination in maize genotypes grown in Europe and Africa. J. Agric. Food. Chem. 1995, 43, 429-434. [CrossRef]

82. De Nijs, M.; Sizoo, E.; Rombouts, F.; Notermans, S.; Van Egmond, H. Fumonisin B1 in maize for food production imported in The Netherlands. Food Addit. Contam. 1998, 15, 389-392. [CrossRef]

83. Kedera, C.; Plattner, R.; Desjardins, A. Incidence of Fusarium spp. and levels of fumonisin B1 in maize in western Kenya. Appl. Environ. Microbiol. 1999, 65, 41-44.

84. Medina-Martínez, M.S.; Martínez, A.J. Mold occurrence and aflatoxin B1 and fumonisin B1 determination in corn samples in Venezuela. J. Agric. Food. Chem. 2000, 48, 2833-2836. [CrossRef]

85. Kim, E.-K.; Shon, D.-H.; Chung, S.-H.; Kim, Y.-B. Survey for fumonisin B1 in Korean corn-based food products. Food Addit. Contam. 2002, 19, 459-464. [CrossRef]

86. Nayaka, S.C.; Shankar, A.U.; Niranjana, S.; Wulff, E.G.; Mortensen, C.; Prakash, H. Detection and quantification of fumonisins from Fusarium verticillioides in maize grown in southern India. World J. Microbiol. Biotechnol. 2010, 26, 71. [CrossRef]

87. Shephard, G.S.; Marasas, W.F.; Leggott, N.L.; Yazdanpanah, H.; Rahimian, H.; Safavi, N. Natural occurrence of fumonisins in corn from Iran. J. Agric. Food. Chem. 2000, 48, 1860-1864. [CrossRef]

88. Yoshizawa, T.; Yamashita, A.; Chokethaworn, N. Occurrence of fumonisins and aflatoxins in corn from Thailand. Food Addit. Contam. 1996, 13, 163-168. [CrossRef]

89. Ueno, Y.; Aoyama, S.; Sugiura, Y.; Wang, D.; Lee, U.; Hirooka, E.; Hara, S.; Karki, T.; Chen, G.; Yu, S. A limited survey of fumonisins in corn and corn-based products in Asian countries. Mycotoxin Res. 1993, 9, $27-34$. [CrossRef]

90. Ali, N.; Sardjono; Yamashita, A.; Yoshizawa, T. Natural co-occurrence of aflatoxins and Fusavium mycotoxins (fumonisins, deoxynivalenol, nivalenol and zearalenone) in corn from Indonesia. Food Addit. Contam. 1998, 15, 377-384. [CrossRef]

91. Palacios, S.A.; Ramirez, M.L.; Cabrera Zalazar, M.; Farnochi, M.C.; Zappacosta, D.; Chiacchiera, S.M.; Reynoso, M.M.; Chulze, S.N.; Torres, A.M. Occurrence of Fusarium spp. and fumonisin in durum wheat grains. J. Agric. Food Chem. 2011, 59, 12264-12269. [CrossRef]

92. Mendes, G.D.R.L.; Reis, T.A.D.; Corrêa, B.; Badiale-Furlong, E. Mycobiota and occurrence of Fumonisin B1 in wheat harvested in Southern Brazil. Ciênc. Rural. 2015, 45, 1050-1057. [CrossRef]

93. Roscoe, V.; Lombaert, G.; Huzel, V.; Neumann, G.; Melietio, J.; Kitchen, D.; Kotello, S.; Krakalovich, T.; Trelka, R.; Scott, P. Mycotoxins in breakfast cereals from the Canadian retail market: A 3-year survey. Food Addit. Contam. 2008, 25, 347-355. [CrossRef]

94. Rodrigues, I.; Naehrer, K. A three-year survey on the worldwide occurrence of mycotoxins in feedstuffs and feed. Toxins 2012, 4, 663-675. [CrossRef]

95. Li, F.; Jiang, D.; Zheng, F.; Chen, J.; Li, W. Fumonisins B1, B2 and B3 in corn products, wheat flour and corn oil marketed in Shandong province of China. Food Addit. Contam. Part B. 2015, 8, 169-174. [CrossRef]

96. Rubert, J.; Soriano, J.M.; Mañes, J.; Soler, C. Occurrence of fumonisins in organic and conventional cereal-based products commercialized in France, Germany and Spain. Food Chem. Toxicol. 2013, 56, 387-391. [CrossRef]

97. Chehri, K.; Jahromi, S.T.; Reddy, K.; Abbasi, S.; Salleh, B. Occurrence of Fusarium spp. and fumonisins in stored wheat grains marketed in Iran. Toxins 2010, 2, 2816-2823. [CrossRef]

98. Cirillo, T.; Ritieni, A.; Galvano, F.; Amodio Cocchieri, R. Natural co-occurrence of deoxynivalenol and fumonisins B1 and B2 in Italian marketed foodstuffs. Food Addit. Contam. 2003, 20, 566-571. [CrossRef]

99. Kushiro, M.; Zheng, Y.; Nagata, R.; Nakagawa, H.; Nagashima, H. Limited surveillance of fumonisins in brown rice and wheat harvested in Japan. J. Food Prot. 2009, 72, 1327-1331. [CrossRef]

100. Stanković, S.; Lević, J.; Ivanović, D.; Krnjaja, V.; Stanković, G.; Tančić, S. Fumonisin B1 and its co-occurrence with other fusariotoxins in naturally-contaminated wheat grain. Food Control 2012, 23, 384-388. [CrossRef]

101. Mashinini, K.; Dutton, M.F. The incidence of fungi and mycotoxins in South Africa wheat and wheat-based products. J. Environ. Sci. Health B. 2006, 41, 285-296. [CrossRef] 
102. Alkadri, D.; Rubert, J.; Prodi, A.; Pisi, A.; Mañes, J.; Soler, C. Natural co-occurrence of mycotoxins in wheat grains from Italy and Syria. Food Chem. 2014, 157, 111-118. [CrossRef]

103. Serrano, A.; Font, G.; Ruiz, M.; Ferrer, E. Co-occurrence and risk assessment of mycotoxins in food and diet from Mediterranean area. Food Chem. 2012, 135, 423-429. [CrossRef]

104. Busman, M.; Desjardins, A.; Proctor, R. Analysis of fumonisin contamination and the presence of Fusarium in wheat with kernel black point disease in the United States. Food Addit. Contam. Part A 2012, 29, 1092-1100. [CrossRef]

105. Gamanya, R.; Sibanda, L. Survey of Fusarium moniliforme (F. verticillioides) and production of fumonisin B1 in cereal grains and oilseeds in Zimbabwe. Int. J. Food Microbiol. 2001, 71, 145-149. [CrossRef]

106. Marin, S.; Ramos, A.; Cano-Sancho, G.; Sanchis, V. Mycotoxins: Occurrence, toxicology, and exposure assessment. Food Chem. Toxicol. 2013, 60, 218-237. [CrossRef] [PubMed]

107. Cao, A.; Santiago, R.; Ramos, A.J.; Marín, S.; Reid, L.M.; Butrón, A. Environmental factors related to fungal infection and fumonisin accumulation during the development and drying of white maize kernels. Int. J. Food Microbiol. 2013, 164, 15-22. [CrossRef] [PubMed]

108. Irzykowska, L.; Bocianowski, J.; Waśkiewicz, A.; Weber, Z.; Karolewski, Z.; Goliński, P.; Kostecki, M.; Irzykowski, W. Genetic variation of Fusarium oxysporum isolates forming fumonisin B 1 and moniliformin. J. Appl. Genet. 2012, 53, 237-247. [CrossRef] [PubMed]

109. Waśkiewicz, A.; Stępień, Ł.; Wilman, K.; Kachlicki, P. Diversity of pea-associated F. proliferatum and F. verticillioides populations revealed by FUM1 sequence analysis and fumonisin biosynthesis. Toxins 2013, 5, 488-503. [CrossRef] [PubMed]

110. Cendoya, E.; Monge, M.P.; Palacios, S.A.; Chiacchiera, S.M.; Torres, A.M.; Farnochi, M.C.; Ramirez, M.L. Fumonisin occurrence in naturally contaminated wheat grain harvested in Argentina. Food Control. 2014, 37, 56-61. [CrossRef]

111. Wong, J.; Jeffries, P. Diversity of pathogenic Fusarium populations associated with asparagus roots in decline soils in Spain and the UK. Plant Physiol. 2006, 55, 331-342. [CrossRef]

112. Karbancıoglu-Güler, F.; Heperkan, D. Natural occurrence of fumonisin B1 in dried figs as an unexpected hazard. Food Chem. Toxicol. 2009, 47, 289-292. [CrossRef] [PubMed]

113. da Silva, S.C.C.; Lala, B.; Carniato, C.; Schamberd, C.R.; Nascimento, C.S.; Braccini, G.L.; Porto, C.; Roldi, G.; Tanamati, F.; Gasparino, E. Fumonisin affects performance and modulates the gene expression of IGF-1 and GHR in Nile tilapia fingerlings and juveniles. Aquaculture 2019, 507, 233-237. [CrossRef]

114. Richard, J.L. Some major mycotoxins and their mycotoxicoses-An overview. Int. J. Food Microbiol. 2007, 119, 3-10. [CrossRef] [PubMed]

115. Gutema, T.; Munimbazi, C.; Bullerman, L.B. Occurrence of fumonisins and moniliformin in corn and corn-based food products of US origin. J. Food Prot. 2000, 63, 1732-1737. [CrossRef]

116. Martins, F.A.; Ferreira, F.M.D.; Ferreira, F.D.; Bando, É.; Nerilo, S.B.; Hirooka, E.Y.; Machinski Jr, M. Daily intake estimates of fumonisins in corn-based food products in the population of Parana, Brazil. Food Control. 2012, 26, 614-618. [CrossRef]

117. Seo, D.-G.; Phat, C.; Kim, D.-H.; Lee, C. Occurrence of Fusarium mycotoxin fumonisin B 1 and B 2 in animal feeds in Korea. Mycotoxin Res. 2013, 29, 159-167. [CrossRef] [PubMed]

118. Abdallah, M.F.; Krska, R.; Sulyok, M. Occurrence of Ochratoxins, Fumonisin B2, Aflatoxins (B1 and B2), and Other Secondary Fungal Metabolites in Dried Date Palm Fruits from Egypt: A Mini-Survey. J. Food Sci. 2018, 83, 559-564. [CrossRef] [PubMed]

119. Rosa Junior, O.F.; Dalcin, M.S.; Nascimento, V.L.; Haesbaert, F.M.; Ferreira, T.P.S.; Fidelis, R.R.; Sarmento, R.A.; Aguiar, R.W.S.; Oliveira, E.E.; Santos, G.R. Fumonisin Production by Fusarium verticillioides in Maize Genotypes Cultivated in Different Environments. Toxins 2019, 11, 215. [CrossRef] [PubMed]

120. Sugita-Konishi, Y.; Nakajima, M.; Tabata, S.; Ishikuro, E.; Tanaka, T.; Norizuki, H.; Itoh, Y.; Aoyama, K.; Fujita, K.; Kai, S. Occurrence of aflatoxins, ochratoxin A, and fumonisins in retail foods in Japan. J. Food Prot. 2006, 69, 1365-1370. [CrossRef] [PubMed]

121. García-Moraleja, A.; Font, G.; Mañes, J.; Ferrer, E. Analysis of mycotoxins in coffee and risk assessment in Spanish adolescents and adults. Food Chem. Toxicol. 2015, 86, 225-233. [CrossRef] [PubMed]

122. Larsen, J.C. Opinion of the Scientific Panel on Contaminants in Food Chain on a request from the Commission related to ergot as undesirable substance in animal feed: Question No EFSA-Q-2003-38. EFSA J. 2005. [CrossRef] 
123. Norred, W.; Plattner, R.; Vesonder, R.; Bacon, C.; Voss, K. Effects of selected secondary metabolites of Fusarium moniliforme on unscheduled synthesis of DNA by rat primary hepatocytes. Food Chem. Toxicol. 1992, 30, 233-237. [CrossRef]

124. Voss, K.; Smith, G.; Haschek, W. Fumonisins: Toxicokinetics, mechanism of action and toxicity. Anim. Feed Sci.Technol. 2007, 137, 299-325. [CrossRef]

125. Bouhet, S.; Oswald, I.P. The intestine as a possible target for fumonisin toxicity. Mol. Nutr. Food Res. 2007, 51, 925-931. [CrossRef]

126. Missmer, S.A.; Suarez, L.; Felkner, M.; Wang, E.; Merrill Jr, A.H.; Rothman, K.J.; Hendricks, K.A. Exposure to fumonisins and the occurrence of neural tube defects along the Texas-Mexico border. Environ. Health Perspect. 2005, 114, 237-241. [CrossRef] [PubMed]

127. Gelderblom, W.C.; Kriek, N.; Marasas, W.; Thiel, P. Toxicity and carcinogenicity of the Fusanum monilzforine metabolite, fumonisin B1, in rats. Carcinogenesis 1991, 12, 1247-1251. [CrossRef] [PubMed]

128. Marasas, D.; WFO, J. Fusarium moniliforme contamination of maize in oesophageal cancer areas in Transkei. S. Afr. Med. J. 1988, 74, 110-114. [PubMed]

129. Franceschi, S.; Bidoli, E.; Barón, A.E.; La Vecchia, C. Maize and risk of cancers of the oral cavity, pharynx, and esophagus in northeastern Italy. J. Natl. Cancer Inst. 1990, 82, 1407-1411. [CrossRef] [PubMed]

130. Dragan, Y.P.; Bidlack, W.R.; Cohen, S.M.; Goldsworthy, T.L.; Hard, G.C.; Howard, P.C.; Riley, R.T.; Voss, K.A. Implications of apoptosis for toxicity, carcinogenicity, and risk assessment: Fumonisin B1 as an example. Toxicol. Sci. 2001, 61, 6-17. [CrossRef] [PubMed]

131. Rumora, L.; Kovačić, S.; Rozgaj, R.; Čepelak, I.; Pepeljnjak, S.; Grubišić, T.Ž. Cytotoxic and genotoxic effects of fumonisin B 1 on rabbit kidney RK13 cell line. Arch. Toxicol. 2002, 76, 55-61. [CrossRef] [PubMed]

132. Sun, G.; Wang, S.; Hu, X.; Su, J.; Huang, T.; Yu, J.; Tang, L.; Gao, W.; Wang, J.-S. Fumonisin B1 contamination of home-grown corn in high-risk areas for esophageal and liver cancer in China. Food Addit. Contam. 2007, 24, 181-185. [CrossRef] [PubMed]

133. Alizadeh, A.M.; Roshandel, G.; Roudbarmohammadi, S.; Roudbary, M.; Sohanaki, H.; Ghiasian, S.A.; Taherkhani, A.; Semnani, S.; Aghasi, M. Fumonisin B1 contamination of cereals and risk of esophageal cancer in a high risk area in northeastern Iran. Asian Pac. J. Cancer Prev. 2012, 13, 2625-2628. [CrossRef] [PubMed]

134. Solfrizzo, M.; Chulze, S.; Mallmann, C.; Visconti, A.; De Girolamo, A.; Rojo, F.; Torres, A. Comparison of urinary sphingolipids in human populations with high and low maize consumption as a possible biomarker of fumonisin dietary exposure. Food Addit. Contam. 2004, 21, 1090-1095. [CrossRef] [PubMed]

135. Haliburton, J.C.; Buck, W.B. Equine leucoencephalomalacia: An historical review. In Diagnosis of Mycotoxicoses; Springer: Berlin/Heidelberg, Germany, 1986; pp. 75-79.

136. Kriek, N.; Kellerman, T.S.; Marasas, W.F.O. A comparative study of the toxicity of Fusarium verticillioides (=F. moniliforme) to horses, primates, pigs, sheep and rats. Onderstepoort J. Vet. Res. 1981, 48, 129-131.

137. Marasas, W.F.; Riley, R.T.; Hendricks, K.A.; Stevens, V.L.; Sadler, T.W.; Gelineau-van Waes, J.; Missmer, S.A.; Cabrera, J.; Torres, O.; Gelderblom, W.C. Fumonisins disrupt sphingolipid metabolism, folate transport, and neural tube development in embryo culture and in vivo: A potential risk factor for human neural tube defects among populations consuming fumonisin-contaminated maize. J. Nutr. 2004, 134, 711-716. [CrossRef] [PubMed]

138. Sadler, T.; Merrill, A.H.; Stevens, V.L.; Sullards, M.C.; Wang, E.; Wang, P. Prevention of fumonisin B1-induced neural tube defects by folic acid. Teratology 2002, 66, 169-176. [CrossRef] [PubMed]

139. Sun, G.; Wang, S.; Hu, X.; Su, J.; Zhang, Y.; Xie, Y.; Zhang, H.; Tang, L.; Wang, J.-S. Co-contamination of aflatoxin B1 and fumonisin B1 in food and human dietary exposure in three areas of China. Food Addit. Contam. 2011, 28, 461-470. [CrossRef] [PubMed]

140. Liverpool-Tasie, L.; Turna, N.S.; Ademola, O.; Obadina, A.; Wu, F. The occurrence and co-occurrence of aflatoxin and fumonisin along the maize value chain in southwest Nigeria. Food Chem. Toxicol. 2019, 129, 458-465. [CrossRef] [PubMed]

141. Mwalwayo, D.S.; Thole, B. Prevalence of aflatoxin and fumonisins (B1+ B2) in maize consumed in rural Malawi. Toxicol. Rep. 2016, 3, 173-179. [CrossRef]

142. Polychronaki, N.; West, R.M.; Turner, P.C.; Amra, H.; Abdel-Wahhab, M.; Mykkänen, H.; El-Nezami, H. A longitudinal assessment of aflatoxin M1 excretion in breast milk of selected Egyptian mothers. Food Chem. Toxicol. 2007, 45, 1210-1215. [CrossRef] 
143. Mahdavi, R.; Nikniaz, L.; Arefhosseini, S.; Jabbari, M.V. Determination of Aflatoxin M 1 in Breast Milk Samples in Tabriz-Iran. Matern. Child Health J. 2010, 14, 141-145. [CrossRef]

144. Magoha, H.; Kimanya, M.; De Meulenaer, B.; Roberfroid, D.; Lachat, C.; Kolsteren, P. Association between aflatoxin M1 exposure through breast milk and growth impairment in infants from Northern Tanzania. Matern. World Mycotoxin J. 2014, 7, 277-284. [CrossRef]

145. Kimanya, M.E.; De Meulenaer, B.; Roberfroid, D.; Lachat, C.; Kolsteren, P. Fumonisin exposure through maize in complementary foods is inversely associated with linear growth of infants in Tanzania. Mol. Nutr. Food Res. 2010, 54, 1659-1667. [CrossRef]

146. Shirima, C.P.; Kimanya, M.E.; Routledge, M.N.; Srey, C.; Kinabo, J.L.; Humpf, H.-U.; Wild, C.P.; Tu, Y.-K.; Gong, Y.Y. A prospective study of growth and biomarkers of exposure to aflatoxin and fumonisin during early childhood in Tanzania. Environ. Health Perspect. 2014, 123, 173-178. [CrossRef]

147. Chen, C.; Mitchell, N.J.; Gratz, J.; Houpt, E.R.; Gong, Y.; Egner, P.A.; Groopman, J.D.; Riley, R.T.; Showker, J.L.; Svensen, E. Exposure to aflatoxin and fumonisin in children at risk for growth impairment in rural Tanzania. Environ. Int. 2018, 115, 29-37. [CrossRef] [PubMed]

148. Michaelsen, K.F. Feeding and Nutrition of Infants and Young Children: Guidelines for the WHO European Region, with Emphasis on the Former Soviet Countries; WHO Regional Office Europe: Copenhagen, Denmark, 2000.

149. Humpf, H.U.; Voss, K.A. Effects of thermal food processing on the chemical structure and toxicity of fumonisin mycotoxins. Mol. Nutr. Food Res. 2004, 48, 255-269. [CrossRef] [PubMed]

150. Falavigna, C.; Cirlini, M.; Galaverna, G.; Dall'Asta, C. Masked fumonisins in processed food: Co-occurrence of hidden and bound forms and their stability under digestive conditions. World Mycotoxin J. 2012, 5, 325-334. [CrossRef]

151. Seefelder, W.; Hartl, M.; Humpf, H.-U. Determination of N-(carboxymethyl) fumonisin B1 in corn products by liquid chromatography/electrospray ionization-mass spectrometry. J. Agric. Food Chem. 2001, 49, $2146-2151$. [CrossRef] [PubMed]

152. Poling, S.M.; Plattner, R.D.; Weisleder, D. N-(1-Deoxy-D-fructos-1-yl) fumonisin B1, the initial reaction product of fumonisin B1 and D-glucose. J. Agric. Food. Chem. 2002, 50, 1318-1324. [CrossRef] [PubMed]

153. Saunders, D.S.; Meredith, F.I.; Voss, K.A. Control of fumonisin: Effects of processing. Environ. Health Perspect. 2001, 109, 333-336. [PubMed]

154. Scudamore, K.; Patel, S. Fusarium mycotoxins in milling streams from the commercial milling of maize imported to the UK, and relevance to current legislation. Food Addit. Contam. 2009, 26, 744-753. [CrossRef] [PubMed]

155. Burger, H.; Shephard, G.; Louw, W.; Rheeder, J.; Gelderblom, W. The mycotoxin distribution in maize milling fractions under experimental conditions. Int. J. Food Microbiol. 2013, 165, 57-64. [CrossRef]

156. Scudamore, K. Fate of Fusarium mycotoxins in the cereal industry: Recent UK studies. World Mycotoxin J. 2008, 1, 315-323. [CrossRef]

157. Schaarschmidt, S.; Fauhl-Hassek, C. Mycotoxins during the Processes of Nixtamalization and Tortilla Production. Toxins 2019, 11, 227. [CrossRef]

158. Bullerman, L.B.; Ryu, D.; Jackson, L.S. Stability of fumonisins in food processing. In Mycotoxins and Food Safety; Springer: Berlin/Heidelberg, Germany, 2002; pp. 195-204.

159. Magan, N. Fungi in extreme environments. Mycota 2007, 4, 85-103.

160. Jurado, M.; Vázquez, C.; Callejas, C.; González-Jaén, M. Occurrence and variability of mycotoxigenic Fusarium species associated to wheat and maize in the South West of Spain. Mycotoxin Res. 2006, 22, 87-91. [CrossRef] [PubMed]

161. Aliakbari, F.; Mirabolfathy, M.; Emami, M.; Mazhar, S.F.; Karami-Osboo, R. Natural occurrence of Fusarium species in maize kernels at Gholestan province in northern Iran. Asian J. Plant Sci. 2007, 8, 1276-1281.

162. Cavaglieri, L.; Keller, K.; Pereyra, C.; Pereyra, M.G.; Alonso, V.; Rojo, F.; Dalcero, A.; Rosa, C. Fungi and natural incidence of selected mycotoxins in barley rootlets. J. Stored Prod. Res. 2009, 45, 147-150. [CrossRef]

163. Gil-Serna, J.; Mateo, E.; González-Jaén, M.; Jiménez, M.; Vázquez, C.; Patiño, B. Contamination of barley seeds with Fusarium species and their toxins in Spain: An integrated approach. Food Addit. Contam. Part A 2013, 30, 372-380. [CrossRef] [PubMed]

164. Magan, N.; Medina, A.; Aldred, D. Possible climate-change effects on mycotoxin contamination of food crops pre-and postharvest. Plant Pathol. 2011, 60, 150-163. [CrossRef] 
165. Munkvold, G.P. Epidemiology of Fusarium diseases and their mycotoxins in maize ears. Eur. J. Plant Pathol. 2003, 109, 705-713. [CrossRef]

166. Maiorano, A.; Reyneri, A.; Magni, A.; Ramponi, C. A decision tool for evaluating the agronomic risk of exposure to fumonisins of different maize crop management systems in Italy. Agric. Syst. 2009, 102, 17-23. [CrossRef]

167. Cao, A.; Santiago, R.; Ramos, A.J.; Souto, X.C.; Aguín, O.; Malvar, R.A.; Butrón, A. Critical environmental and genotypic factors for Fusarium verticillioides infection, fungal growth and fumonisin contamination in maize grown in northwestern Spain. Int. J. Food Microbiol. 2014, 177, 63-71. [CrossRef]

168. Czembor, E.; Waśkiewicz, A.; Piechota, U.; Puchta, M.; Czembor, J.H.; Stepien, L. Differences in ear rot resistance and Fusarium verticillioides-produced fumonisin contamination between Polish currently and historically used maize inbred lines. Front. Microbiol. 2019, 10, 449. [CrossRef]

169. Cendoya, E.; del Pilar Monge, M.; Chiacchiera, S.M.; Farnochi, M.C.; Ramirez, M.L. Influence of water activity and temperature on growth and fumonisin production by Fusarium proliferatum strains on irradiated wheat grains. Int. J. Food Microbiol. 2018, 266, 158-166. [CrossRef] [PubMed]

170. Kohut, G.; Ádám, A.L.; Fazekas, B.; Hornok, L. N-starvation stress induced FUM gene expression and fumonisin production is mediated via the HOG-type MAPK pathway in Fusarium proliferatum. Int. J. Food Microbiol. 2009, 130, 65-69. [CrossRef] [PubMed]

171. Li, T.; Gong, L.; Wang, Y.; Chen, F.; Gupta, V.K.; Jian, Q.; Duan, X.; Jiang, Y. Proteomics analysis of Fusarium proliferatum under various initial $\mathrm{pH}$ during fumonisin production. J. Proteom. 2017, 164, 59-72. [CrossRef] [PubMed]

172. Keller, S.; Sullivan, T.; Chirtel, S. Factors affecting the growth of Fusarium proliferatum and the production of fumonisin B 1: Oxygen and pH. J. Ind. Microbiol. Biotechnol. 1997, 19, 305-309. [CrossRef] [PubMed]

173. Horwitz, W.; Latimer, J.G. (Eds.) Official Methods of Analysis of AOAC International; AOAC International: Gaithersburg, MD, USA, 2005.

174. Arroyo-Manzanares, N.; Huertas-Pérez, J.F.; Gámiz-Gracia, L.; García-Campaña, A.M. Simple and efficient methodology to determine mycotoxins in cereal syrups. Food Chem. 2015, 177, 274-279. [CrossRef]

175. Bolechová, M.; Benešová, K.; Běláková, S.; Čáslavský, J.; Pospíchalová, M.; Mikulíková, R. Determination of seventeen mycotoxins in barley and malt in the Czech Republic. Food Control. 2015, 47, 108-113. [CrossRef]

176. Nielsen, K.F.; Ngemela, A.F.; Jensen, L.B.; De Medeiros, L.S.; Rasmussen, P.H. UHPLC-MS/MS determination of ochratoxin A and fumonisins in coffee using QuEChERS extraction combined with mixed-mode SPE purification. J. Agric. Food Chem. 2015, 63, 1029-1034. [CrossRef] [PubMed]

177. Wang, Y.; Xiao, C.; Guo, J.; Yuan, Y.; Wang, J.; Liu, L.; Yue, T. Development and Application of a Method for the Analysis of 9 Mycotoxins in Maize by HPLC-MS/MS. J. Food Sci. 2013, 78, M1752-M1756. [CrossRef] [PubMed]

178. Ediage, E.N.; Van Poucke, C.; De Saeger, S. A multi-analyte LC-MS/MS method for the analysis of 23 mycotoxins in different sorghum varieties: The forgotten sample matrix. Food Chem. 2015, 177, 397-404. [CrossRef] [PubMed]

179. Jung, S.-Y.; Choe, B.-C.; Choi, E.-J.; Jeong, H.-J.; Hwang, Y.-S.; Shin, G.-Y.; Kim, J.-H. Survey of mycotoxins in commonly consumed Korean grain products using an LC-MS/MS multimycotoxin method in combination with immunoaffinity clean-up. Food Sci. Biotechnol. 2015, 24, 1193-1199. [CrossRef]

180. Bryła, M.; Roszko, M.; Szymczyk, K.; Jędrzejczak, R.; Obiedziński, M.W. Fumonisins and their masked forms in maize products. Food Control 2016, 59, 619-627. [CrossRef]

181. Beltrán, E.; Ibáñez, M.; Portolés, T.; Ripollés, C.; Sancho, J.V.; Yusà, V.; Marín, S.; Hernández, F. Development of sensitive and rapid analytical methodology for food analysis of 18 mycotoxins included in a total diet study. Anal. Chim. Acta 2013, 783, 39-48. [CrossRef] [PubMed]

182. García-Moraleja, A.; Font, G.; Mañes, J.; Ferrer, E. Development of a new method for the simultaneous determination of 21 mycotoxins in coffee beverages by liquid chromatography tandem mass spectrometry. Food Res. Int. 2015, 72, 247-255. [CrossRef]

183. Rubert, J.; Dzuman, Z.; Vaclavikova, M.; Zachariasova, M.; Soler, C.; Hajslova, J. Analysis of mycotoxins in barley using ultra high liquid chromatography high resolution mass spectrometry: Comparison of efficiency and efficacy of different extraction procedures. Talanta 2012, 99, 712-719. [CrossRef] [PubMed] 
184. Blesa, J.; Moltó, J.-C.; El Akhdari, S.; Mañes, J.; Zinedine, A. Simultaneous determination of Fusarium mycotoxins in wheat grain from Morocco by liquid chromatography coupled to triple quadrupole mass spectrometry. Food Control. 2014, 46, 1-5. [CrossRef]

185. Arroyo-Manzanares, N.; Huertas-Pérez, J.F.; Gámiz-Gracia, L.; García-Campaña, A.M. A new approach in sample treatment combined with UHPLC-MS/MS for the determination of multiclass mycotoxins in edible nuts and seeds. Talanta 2013, 115, 61-67. [CrossRef]

186. Ye, H.; Lai, X.; Liu, C. Determination of Fumonisin B 1 and B 2 in Corn Using Matrix-Phase Dispersion Coupled to High Performance Liquid Chromatography. Asian J. Chem. 2013, 25, 6807-6810. [CrossRef]

187. Petrarca, M.H.; Rodrigues, M.I.; Rossi, E.A.; de Sylos, C.M. Optimisation of a sample preparation method for the determination of fumonisin B1 in rice. Food Chem. 2014, 158, 270-277. [CrossRef]

188. Petrarca, M.H.; Rossi, E.A.; de Sylos, C.M. In-house method validation, estimating measurement uncertainty and the occurrence of fumonisin B1 in samples of Brazilian commercial rice. Food Control 2016, 59, 439-446. [CrossRef]

189. Zhang, K.; Wong, J.W.; Hayward, D.G.; Vaclavikova, M.; Liao, C.-D.; Trucksess, M.W. Determination of mycotoxins in milk-based products and infant formula using stable isotope dilution assay and liquid chromatography tandem mass spectrometry. J. Agric. Food Chem. 2013, 61, 6265-6273. [CrossRef]

190. Azaiez, I.; Giusti, F.; Sagratini, G.; Mañes, J.; Fernández-Franzón, M. Multi-mycotoxins analysis in dried fruit by LC/MS/MS and a modified QuEChERS procedure. Food Anal. Methods 2014, 7, 935-945. [CrossRef]

191. Liao, C.-D.; Wong, J.W.; Zhang, K.; Yang, P.; Wittenberg, J.B.; Trucksess, M.W.; Hayward, D.G.; Lee, N.S.; Chang, J.S. Multi-mycotoxin analysis of finished grain and nut products using ultrahigh-performance liquid chromatography and positive electrospray ionization-quadrupole orbital ion trap high-resolution mass spectrometry. J. Agric. Food Chem. 2015, 63, 8314-8332. [CrossRef] [PubMed]

192. Soares, C.; Rodrigues, P.; Freitas-Silva, O.; Abrunhosa, L.; Venâncio, A. HPLC method for simultaneous detection of aflatoxins and cyclopiazonic acid. World Mycotoxin J. 2010, 3, 225-231. [CrossRef]

193. Liu, X.; Xu, Y.; He, Q.-H.; He, Z.-Y.; Xiong, Z.-P. Application of mimotope peptides of fumonisin B1 in Peptide ELISA. J. Agric. Food Chem. 2013, 61, 4765-4770. [CrossRef] [PubMed]

194. Ran, R.; Wang, C.; Han, Z.; Wu, A.; Zhang, D.; Shi, J. Determination of deoxynivalenol (DON) and its derivatives: Current status of analytical methods. Food Control. 2013, 34, 138-148. [CrossRef]

195. Lee, N.A.; Wang, S.; Allan, R.D.; Kennedy, I.R. A rapid aflatoxin B1 ELISA: Development and validation with reduced matrix effects for peanuts, corn, pistachio, and soybeans. J. Agric. Food Chem. 2004, 52, 2746-2755. [CrossRef] [PubMed]

196. Nagaraj, D.; Adkar-Purushothama, C.R.; Yanjarappa, S.M. Multiplex PCR for the early detection of fumonisin producing Fusarium verticillioides. Food Biosci. 2016, 13, 84-88. [CrossRef]

197. Sreenivasa, M.; Dass, R.S.; Raj, A.C.; Janardhana, G. Molecular detection of fumonisin producing Fusarium species of freshly harvested maize kernels using polymerase chain reaction (PCR). Taiwania 2006, 51, 251-257.

198. Bintvihok, A.; Treebonmuang, S.; Srisakwattana, K.; Nuanchun, W.; Patthanachai, K.; Usawang, S. A rapid and sensitive detection of aflatoxin-producing fungus using an optimized polymerase chain reaction (PCR). Toxicol. Res. 2016, 32, 81-87. [CrossRef]

199. Niessen, L. PCR-based diagnosis and quantification of mycotoxin-producing fungi. In Advances in Food and Nutrition Research; Elsevier: Amsterdam, The Netherlands, 2008; Volume 54, pp. 81-138.

200. Omori, A.M.; Ono, E.Y.S.; Bordini, J.G.; Hirozawa, M.T.; Fungaro, M.H.P.; Ono, M.A. Detection of Fusarium verticillioides by PCR-ELISA based on FUM21 gene. Food Microbiol. 2018, 73, 160-167. [CrossRef]

201. Tang, X.; Li, P.; Zhang, Z.; Zhang, Q.; Guo, J.; Zhang, W. An ultrasensitive gray-imaging-based quantitative immunochromatographic detection method for fumonisin B1 in agricultural products. Food Control. 2017, 80, 333-340. [CrossRef]

202. Del Fiore, A.; Reverberi, M.; Ricelli, A.; Pinzari, F.; Serranti, S.; Fabbri, A.; Bonifazi, G.; Fanelli, C. Early detection of toxigenic fungi on maize by hyperspectral imaging analysis. Int. J. Food Microbiol. 2010, 144, 64-71. [CrossRef] [PubMed]

203. Kimuli, D.; Wang, W.; Lawrence, K.C.; Yoon, S.-C.; Ni, X.; Heitschmidt, G.W. Utilisation of visible/near-infrared hyperspectral images to classify aflatoxin B1 contaminated maize kernels. Biosyst. Eng. 2018, 166, 150-160. [CrossRef] 
204. Di Nardo, F.; Alladio, E.; Baggiani, C.; Cavalera, S.; Giovannoli, C.; Spano, G.; Anfossi, L. Colour-encoded lateral flow immunoassay for the simultaneous detection of aflatoxin B1 and type-B fumonisins in a single Test line. Talanta 2019, 192, 288-294. [CrossRef] [PubMed]

205. Lu, L.; Seenivasan, R.; Wang, Y.-C.; Yu, J.-H.; Gunasekaran, S. An electrochemical immunosensor for rapid and sensitive detection of mycotoxins fumonisin B1 and deoxynivalenol. Electrochim. Acta 2016, 213, 89-97. [CrossRef]

206. Mao, L.; Ji, K.; Yao, L.; Xue, X.; Wen, W.; Zhang, X.; Wang, S. Molecularly imprinted photoelectrochemical sensor for fumonisin B1 based on GO-CdS heterojunction. Biosens. Bioelectron. 2019, 127, 57-63. [CrossRef] [PubMed]

207. Miller, J.D.; Young, J.C.; Trenholm, H.L. Fusarium toxins in field corn. I. Time course of fungal growth and production of deoxynivalenol and other mycotoxins. Can. J. Bot. 1983, 61, 3080-3087. [CrossRef]

208. Scott, P.M.; Nelson, K.; Kanhere, S.R.; Karpinski, K.F.; Hayward, S.; Neish, G.A.; Teich, A.H. Decline in deoxynivalenol (vomitoxin) concentrations in 1983 Ontario winter wheat before harvest. Appl. Environ. Microbiol. 1984, 48, 884-886.

209. Gareis, M.; Bauer, J.; Thiem, J.; Plank, G.; Grabley, S.; Gedek, B. Cleavage of zearalenone-glycoside, a "masked" mycotoxin, during digestion in swine. J. Vet. Med. B 1990, 37, 236-240. [CrossRef]

210. Berthiller, F.; Maragos, C.M.; Dall'Asta, C. Introduction to masked mycotoxins. In Masked Mycotoxins in Food: Formation, Occurrence and Toxicological Relevance; Royal Society of Chemistry, RSC Publishing: Cambridge, UK, 2015; pp. 1-13. [CrossRef]

211. Dellafiora, L.; Dall'Asta, C. Masked mycotoxins: An emerging issue that makes renegotiable what is ordinary. Food Chem. 2016, 213, 534-535. [CrossRef]

212. Tran, S.; Smith, T. Determination of optimal conditions for hydrolysis of conjugated deoxynivalenol in corn and wheat with trifluoromethanesulfonic acid. Anim. Feed Sci. Technol. 2011, 163, 84-92. [CrossRef]

213. McCormick, S.P.; Kato, T.; Maragos, C.M.; Busman, M.; Lattanzio, V.M.; Galaverna, G.; Dall-Asta, C.; Crich, D.; Price, N.P.; Kurtzman, C.P. Anomericity of T-2 toxin-glucoside: Masked mycotoxin in cereal crops. J. Agric. Food Chem. 2015, 63, 731-738. [CrossRef] [PubMed]

214. De Boevre, M.; Di Mavungu, J.D.; Landschoot, S.; Audenaert, K.; Eeckhout, M.; Maene, P.; Haesaert, G.; De Saeger, S. Natural occurrence of mycotoxins and their masked forms in food and feed products. World Mycotoxin J. 2012, 5, 207-219. [CrossRef]

215. Binder, S.; Schwartz-Zimmermann, H.; Varga, E.; Bichl, G.; Michlmayr, H.; Adam, G.; Berthiller, F. Metabolism of zearalenone and its major modified forms in pigs. Toxins 2017, 9, 56. [CrossRef] [PubMed]

216. Duvick, J.; Rood, T.; Maddox, J.; Gilliam, J. Molecular Genetics of Host-Specific Toxins in Plant Disease; Springer: Berlin/Heidelberg, Germany, 1998; pp. 369-381.

217. Blackwell, B.A.; Gilliam, J.T.; Savard, M.E.; David Miller, J.; Duvick, J.P. Oxidative deamination of hydrolyzed fumonisin B1 (AP1) by cultures of Exophiala spinifera. Nat. Toxins 1999, 7, 31-38. [CrossRef]

218. Duvick, J.; Maddox, J.; Gilliam, J. Compositions and methods for fumonisin detoxification. U.S. Patent US6482621B1, 19 November 2002.

219. Gu, M.J.; Han, S.E.; Hwang, K.; Mayer, E.; Reisinger, N.; Schatzmayr, D.; Park, B.-C.; Han, S.H.; Yun, C.-H. Hydrolyzed fumonisin B1 induces less inflammatory responses than fumonisin B1 in the co-culture model of porcine intestinal epithelial and immune cells. Toxicol. Lett. 2019, 305, 110-116. [CrossRef] [PubMed]

220. Benedetti, R.; Nazzi, F.; Locci, R.; Firrao, G. Degradation of fumonisin B1 by a bacterial strain isolated from soil. Biodegradation 2006, 17, 31-38. [CrossRef]

221. Täubel, M. Isolierung und Charakterisierung von Mikroorganismen zur biologischen Inaktivierung von Fumonisinen. Doctoral thesis, University of Natural Resources and Applied Life Sciences, Vienna, Austria, 2005.

222. Heinl, S.; Hartinger, D.; Thamhesl, M.; Vekiru, E.; Krska, R.; Schatzmayr, G.; Moll, W.-D.; Grabherr, R. Degradation of fumonisin B1 by the consecutive action of two bacterial enzymes. J. Biotechnol. 2010, 145, 120-129. [CrossRef]

223. Velluti, A.; Sanchis, V.; Ramos, A.; Egido, J.; Marın, S. Inhibitory effect of cinnamon, clove, lemongrass, oregano and palmarose essential oils on growth and fumonisin B1 production by Fusarium proliferatum in maize grain. Int. J. Food Microbiol. 2003, 89, 145-154. [CrossRef] 
224. Patil, J.R.; Jayaprakasha, G.; Murthy, K.C.; Tichy, S.E.; Chetti, M.B.; Patil, B.S. Apoptosis-mediated proliferation inhibition of human colon cancer cells by volatile principles of Citrus aurantifolia. Food Chem. 2009, 114, 1351-1358. [CrossRef]

225. Driehuis, F.; Te Giffel, M.; Van Egmond, H.; Fremy, J.; Blüthgen, A. Feed-associated mycotoxins in the dairy chain: Occurrence and control. Fil-Idf Bull. Fed. Int. Lait. Int. Dairy Fed. Brussels - Belgium 2010, 444, 2.

226. Okabe, I.; Hiraoka, H.; Miki, K. Influence of harvest time on fumonisin contamination of forage maize for whole-crop silage. Mycoscience 2015, 56, 470-475. [CrossRef]

227. Bush, B.; Carson, M.; Cubeta, M.; Hagler, W.; Payne, G. Infection and fumonisin production by Fusarium verticillioides in developing maize kernels. Phytopathology 2004, 94, 88-93. [CrossRef] [PubMed]

228. Johnson, L.; Harrison, J.; Hunt, C.; Shinners, K.; Doggett, C.; Sapienza, D. Nutritive value of corn silage as affected by maturity and mechanical processing: A contemporary review. J. Dairy Sci. 1999, 82, 2813-2825. [CrossRef]

229. Shephard, G.S.; Burger, H.-M.; Rheeder, J.P.; Alberts, J.F.; Gelderblom, W.C. The effectiveness of regulatory maximum levels for fumonisin mycotoxins in commercial and subsistence maize crops in South Africa. Food Control 2019, 97,77-80. [CrossRef]

230. Miller, J.D. Factors that affect the occurrence of fumonisin. Environ. Health Perspect. 2001, 109, 321-324. [PubMed]

231. van der Westhuizen, L.; Shephard, G.S.; Burger, H.M.; Rheeder, J.P.; Gelderblom, W.C.; Wild, C.P.; Gong, Y.Y. Fumonisin B1 as a urinary biomarker of exposure in a maize intervention study among South African subsistence farmers. Cancer Epidemiol. Biomark. Prev. 2011, 20, 483-489. [CrossRef] [PubMed]

232. Falcão, V.C.A.; Ono, M.A.; de Ávila Miguel, T.; Vizoni, E.; Hirooka, E.Y.; Ono, E.Y.S. Fusarium verticillioides: Evaluation of fumonisin production and effect of fungicides on in vitro inhibition of mycelial growth. Mycopathologia 2011, 171, 77-84. [CrossRef]

233. Miguel, T.Á.; Bordini, J.G.; Saito, G.H.; Andrade, C.G.J.; Ono, M.A.; Hirooka, E.Y.; Vizoni, É.; Ono, E. Effect of fungicide on Fusarium verticillioides mycelial morphology and fumonisin B1 production. Braz. J. Microbiol. 2015, 46, 293-299. [CrossRef] [PubMed]

234. Masiello, M.; Somma, S.; Ghionna, V.; Logrieco, A.F.; Moretti, A. In Vitro and in Field Response of Different Fungicides against Aspergillus flavus and Fusarium Species Causing Ear Rot Disease of Maize. Toxins 2019, 11, 11. [CrossRef]

235. Schmidt-Heydt, M.; Geisen, R. Gene expression as an indication for ochratoxin A biosynthesis in Penicillium nordicum. Mycotoxin Res. 2007, 23, 13-21. [CrossRef] [PubMed]

236. Schmidt-Heydt, M.; Magan, N.; Geisen, R. Stress induction of mycotoxin biosynthesis genes by abiotic factors. FEMS Microbiol. Lett. 2008, 284, 142-149. [CrossRef] [PubMed]

237. Marín, P.; Magan, N.; Vázquez, C.; González-Jaén, M.T. Differential effect of environmental conditions on the growth and regulation of the fumonisin biosynthetic gene FUM1 in the maize pathogens and fumonisin producers Fusarium verticillioides and Fusarium proliferatum. FEMS Microbiol. Ecol. 2010, 73, 303-311. [CrossRef] [PubMed]

238. Bernhoft, A.; Torp, M.; Clasen, P.-E.; Løes, A.-K.; Kristoffersen, A. Influence of agronomic and climatic factors on Fusarium infestation and mycotoxin contamination of cereals in Norway. Food Addit. Contam. Part A 2012, 29, 1129-1140. [CrossRef] [PubMed]

239. Lemmens, M.; Buerstmayr, H.; Krska, R.; Schuhmacher, R.; Grausgruber, H.; Ruckenbauer, P. The effect of inoculation treatment and long-term application of moisture on Fusarium head blight symptoms and deoxynivalenol contamination in wheat grains. Eur. J. Plant Pathol. 2004, 110, 299-308. [CrossRef]

240. Haidukowski, M.; Pascale, M.; Perrone, G.; Pancaldi, D.; Campagna, C.; Visconti, A. Effect of fungicides on the development of Fusarium head blight, yield and deoxynivalenol accumulation in wheat inoculated under field conditions with Fusarium graminearum and Fusarium culmorum. J. Sci. Food Agric. 2005, 85, 191-198. [CrossRef]

241. Yoshida, M.; Nakajima, T.; Tomimura, K.; Suzuki, F.; Arai, M.; Miyasaka, A. Effect of the timing of fungicide application on Fusarium head blight and mycotoxin contamination in wheat. Plant Dis. 2012, 96, 845-851. [CrossRef]

242. Scarpino, V.; Reyneri, A.; Sulyok, M.; Krska, R.; Blandino, M. Effect of fungicide application to control Fusarium head blight and 20 Fusarium and Alternaria mycotoxins in winter wheat (Triticum aestivum L.). World Mycotoxin J. 2015, 8, 499-510. [CrossRef] 
243. Alberts, J.F.; Van Zyl, W.H.; Gelderblom, W.C. Biologically based methods for control of fumonisin-producing Fusarium species and reduction of the fumonisins. Front. Microbiol. 2016, 7, 548. [CrossRef]

244. Jacela, J.Y.; DeRouchey, J.M.; Tokach, M.D.; Goodband, R.D.; Nelssen, J.L.; Renter, D.G.; Dritz, S.S. Feed additives for swine: Fact sheets-flavors and mold inhibitors, mycotoxin binders, and antioxidants. Kansas Agric. Exp. Station Res. Rep. 2010, 10, 27-32. [CrossRef]

245. Kolosova, A.; Stroka, J. Substances for reduction of the contamination of feed by mycotoxins: A review. World Mycotoxin J. 2011, 4, 225-256. [CrossRef]

246. Kabak, B.; Dobson, A.D. Biological strategies to counteract the effects of mycotoxins. J. Food Prot. 2009, 72, 2006-2016. [CrossRef] [PubMed]

247. Whitlow, L.W. Evaluation of mycotoxin binders. In Proceedings of the 4th Mid-Atlantic Nutrition Conference, Timonium, Maryland, 2006; pp. 132-143.

248. De Mil, T.; Devreese, M.; De Baere, S.; Van Ranst, E.; Eeckhout, M.; De Backer, P.; Croubels, S. Characterization of 27 mycotoxin binders and the relation with in vitro zearalenone adsorption at a single concentration. Toxins 2015, 7, 21-33. [CrossRef] [PubMed]

249. Nazarizadeh, H.; Pourreza, J. Evaluation of three mycotoxin binders to prevent the adverse effects of aflatoxin B1 in growing broilers. J. Appl. Anim. Res. 2019, 47, 135-139. [CrossRef]

(C) 2019 by the authors. Licensee MDPI, Basel, Switzerland. This article is an open access article distributed under the terms and conditions of the Creative Commons Attribution (CC BY) license (http://creativecommons.org/licenses/by/4.0/). 